1996

\title{
Habitat Persistence Underlies Intraspecific Variation in the Dispersal Strategies of Planthoppers
}

Robert F. Denno

George K. Roderick

Merrill A. Peterson

Western Washington University, merrill.peterson@wwu.edu

Andrea F. Huberty

Hartmut G. Dobel

See next page for additional authors

Follow this and additional works at: https://cedar.wwu.edu/biology_facpubs

Part of the Biology Commons, and the Entomology Commons

\section{Recommended Citation}

Denno, Robert F.; Roderick, George K.; Peterson, Merrill A.; Huberty, Andrea F.; Dobel, Hartmut G.; Eubanks, Micky D.; Losey, John E.; and Longellotto, Gail A., "Habitat Persistence Underlies Intraspecific Variation in the Dispersal Strategies of Planthoppers" (1996). Biology Faculty and Staff Publications. 45.

https://cedar.wwu.edu/biology_facpubs/45

This Article is brought to you for free and open access by the Biology at Western CEDAR. It has been accepted for inclusion in Biology Faculty and Staff Publications by an authorized administrator of Western CEDAR. For more information, please contact westerncedar@wwu.edu. 
Authors

Robert F. Denno, George K. Roderick, Merrill A. Peterson, Andrea F. Huberty, Hartmut G. Dobel, Micky D.

Eubanks, John E. Losey, and Gail A. Longellotto 
Habitat Persistence Underlies Intraspecific Variation in the Dispersal Strategies of Planthoppers Author(s): Robert F. Denno, George K. Roderick, Merrill A. Peterson, Andrea F. Huberty, Hartmut G. Dobel, Micky D. Eubanks, John E. Losey and Gail A. Langellotto

Source: Ecological Monographs, Vol. 66, No. 4 (Nov., 1996), pp. 389-408

Published by: Ecological Society of America

Stable URL: http://www.jstor.org/stable/2963487

Accessed: 01-10-2015 16:54 UTC

Your use of the JSTOR archive indicates your acceptance of the Terms \& Conditions of Use, available at http://www.jstor.org/page/ info/about/policies/terms.jsp

JSTOR is a not-for-profit service that helps scholars, researchers, and students discover, use, and build upon a wide range of content in a trusted digital archive. We use information technology and tools to increase productivity and facilitate new forms of scholarship. For more information about JSTOR, please contact support@jstor.org. 


\title{
HABITAT PERSISTENCE UNDERLIES INTRASPECIFIC VARIATION IN THE DISPERSAL STRATEGIES OF PLANTHOPPERS $^{1}$
}

\author{
Robert F. Denno, George K. Roderick, Merrill A. Peterson, \\ Andrea F. Huberty, Hartmut G. Döbel, Micky D. Eubanks, \\ John E. Losey, AND GaIl A. LANGellotto \\ Department of Entomology, University of Maryland, \\ College Park, Maryland 20742 USA
}

\begin{abstract}
Dispersal is considered a vital life history characteristic for insects exploiting temporary habitats, and life history theorists have often hypothesized an inverse relationship between dispersal capability and habitat persistence. Most often, this hypothesis has been tested using interspecific comparisons of dispersal capability and qualitative estimates of habitat persistence. Consequently, most assessments have failed to control for possible phylogenetic nonindependence and they also lack quantitative rigor.

We capitalized on existing intraspecific variation in the dispersal capability of Prokelisia planthoppers to examine the relationship between habitat persistence and dispersal, thereby minimizing possible phylogenetic effects. Two congeneric species (Prokelisia marginata and $P$. dolus) occur in the intertidal marshes of North America, where they feed exclusively on cordgrasses (Spartina). Because these planthoppers exhibit wing dimorphism, flightcapable adults (macropters with fully developed wings) are easily differentiated from flightless adults (brachypters with reduced wings). Thus, dispersal capability can be readily estimated by the percentage of macropters in a population.

At a regional spatial scale, we found a highly significant negative relationship between dispersal capability (percent macroptery) and habitat persistence. In this system, habitat persistence is influenced by a combination of marsh elevation, winter severity, and tidal range, which interact to determine the ability of planthoppers to endure through winter in their primary habitat for development. $P$. marginata develops primarily in low-marsh habitats during summer, habitats that can be subjected to pronounced winter disturbance due to ice scouring and/or extensive tidal inundation. Levels of winter disturbance of the low marsh are extreme along the Atlantic coast, intermediate along the Pacific, and low along the Gulf. Both the failure of $P$. marginata populations to remain through winter in this habitat, and the dispersal ability of these populations $(92 \%, 29 \%$, and $17 \%$ macroptery, respectively), are correlated with levels of disturbance. Thus, in regions where winter disturbance is high, levels of dispersal are correspondingly high to allow for recolonization of extirpated habitats from overwintering sites on the high marsh. Unlike P. marginata, $P$. dolus develops primarily in high-marsh habitats, which are much less disturbed on all coasts during winter. Consequently, this species remains year-round in its primary habitat for development, and most populations exhibit relatively low levels of macroptery $(<10 \%)$.

When raised under common garden conditions, many more macropters of both species were produced from Atlantic compared to Gulf populations. Thus the proportion of macropters produced from the populations used in this experiment paralleled the incidence of macroptery measured in the field, providing evidence that the geographic variation in dispersal capability in both species has in part a genetic basis. The results of this study provide strong intraspecific evidence for an inverse relationship between the dispersal capability of insects and the persistence of their habitats.
\end{abstract}

Key words: dispersal, habitat disturbance and persistence, life history strategy, planthopper, Prokelisia marginata, Prokelisia dolus, salt marsh, Spartina, wing polymorphism.

\section{INTRODUCTION}

Historically, dispersal by flight has been considered essential for the success of insect species exploiting temporary habitats (Southwood 1962, 1977). In contrast, dispersal in persistent habitats is not nearly as

\footnotetext{
${ }^{1}$ Manuscript received 26 September 1995; revised 7 March 1996; accepted 12 March 1996.
}

important (Southwood 1962). Thus, in persistent habitats, the evolution of dispersal may be greatly influenced by trade-offs with other life history demands (Roff 1986a, 1994, Denno et al. 1989). For example, in a wide variety of insect species there is a cost to dispersal that results in delayed reproduction and/or reduced fecundity (Roff 1984, 1986a, Zera 1984, Dixon 1985, Denno et al. 1989). Because of these reproductive costs, insects should exhibit reduced dispersal 
in persistent compared to temporary habitats (Roff 1990, Denno et al. 1991). Despite the abundance of theory that predicts elevated levels of dispersal in ephemeral, patchy habitats (Reddingius and den Boer 1970, Roff 1974a, b, 1986a, 1990, Denno 1983, Fahrig 1990), there have been few rigorous empirical studies documenting an inverse relationship between habitat persistence and the incidence of dispersal (see Roff 1990, Denno et al. 1991).

Several factors have hindered investigations of the relationship between habitat persistence and dispersal. First, determining the fraction of potential dispersers in a population is problematic because many insect species are monomorphic for wing length and potential dispersers are not easily differentiated from nondispersers (Denno 1994b). Second, quantifying habitat persistence is not easy because it requires a knowledge of the length of both the time a habitat remains suitable for development and the generation time of the organism in question (Southwood 1962, Southwood et al. 1974, Roff 1990, Denno et al. 1991). Third, variation in dispersal capability is often greater among related species (e.g., the flightless and volant species of grasshoppers, crickets, water striders, planthoppers, and ground beetles) than it is among populations of the same species (Vepsäläinen 1978, den Boer et al. 1980, Roff 1990, Denno et al. 1991, Denno 1994b). As a consequence of these difficulties, most insect studies assessing the relationship between habitat persistence and the incidence of dispersal have been qualitative in nature, have relied on interspecific comparisons (reviewed in Roff 1990), and are possibly confounded by phylogenetic nonindependence (Wagner and Liebherr 1992, but see Denno et al. 1991).

A less confounded approach is to study intraspecific variation in the incidence of dispersal among populations and the underlying cause of this variation. Planthoppers in the genus Prokelisia (Homoptera: Delphacidae) exhibit intraspecific geographic variation in dispersal tendency (Denno et al. 1991, Denno 1994b), and thereby provide a unique opportunity to explore the effect of habitat persistence on the incidence of flight capability. Furthermore, Prokelisia planthoppers are wing dimorphic, facilitating the identification of potential dispersers in different populations (Denno et al. 1987, Denno and Roderick 1990, 1992).

Two congeners, Prokelisia marginata and $P$. dolus, are native residents of the intertidal marshes along the Atlantic, Gulf, and Pacific coasts of North America where they feed and develop exclusively on cordgrass (Spartina) (Denno et al. 1987, Denno 1994a, b). Spartina occupies a variety of saltmarsh habitats at both north temperate and subtropical latitudes, and is exposed to significant geographic variation in winter disturbance and tidal inundation (Blum 1968, Kirby and Gosselink 1976, Turner 1976, Denno and Grissell 1979, Zedler et al. 1992). Such variation in disturbance may influence the persistence of Spartina habitats for plant- hopper exploitation. Thus, this system offers a novel opportunity for testing the hypothesis that intraspecific variation in dispersal capability parallels variation in habitat persistence. In this report, we first establish the primary habitat for development of each Prokelisia species over a broad geographic scale and assess the ability of each to remain in that habitat year-round. Second, we detail intraspecific variation in the dispersal capability of Prokelisia planthoppers within and among regions. Third, we correlate variation in dispersal capability with variation in habitat persistence, as measured by the ability of planthoppers to remain throughout the year in their primary developmental habitat. Last, we provide evidence that geographic variation in the dispersal capability of each Prokelisia species is genetically based, and thereby reflects underlying variation in life history strategies.

\section{NAtural History OF Planthoppers AND Their HOST Plants}

\section{Geographic distribution of cordgrass host plants and saltmarsh planthoppers}

Two species of closely related perennial cordgrass, Spartina alterniflora Lois. and Spartina foliosa Trin., serve as the only recorded host plants for the planthoppers Prokelisia marginata and Prokelisia dolus (Denno et al. 1987). Both cordgrass species are limited to intertidal salt marshes and are native to only the New World (Mobberley 1956). S. alterniflora is broadly distributed along the Atlantic and Gulf coasts of North and Central America and the Atlantic coast of South America (Mobberley 1956). In addition, S. alterniflora has been introduced along the Pacific coast of North America where it now occurs from northern California to Washington (Mobberley 1956, Aberle 1990, Callaway and Josselyn 1992, Daehler and Strong 1994, Stiller and Denton 1995).

$S$. foliosa has a more restricted native distribution, occurring only along the Pacific coast of North America in California and Mexico (Mobberley 1956). This grass occurs in the San Francisco Bay area, is absent south along a 500-km stretch of coast, and appears again in southern California and Baja California where it occurs as isolated patches in secluded estuaries (Mobberley 1956, Neuenschwander et al. 1979, Zedler 1982, 1993, Roberts 1989, Zedler et al. 1992).

Prokelisia marginata and $P$. dolus occur sympatrically along much of the Atlantic and Gulf coasts of North America where they feed and develop exclusively on Spartina alterniflora (Denno et al. 1987). Along the Pacific coast, the two planthoppers are allopatric; $P$. marginata occurs in northern California on both $S$. foliosa (Roderick 1987) and on the introduced populations of $S$. alterniflora (Daehler and Strong 1994), whereas $P$. dolus feeds and reproduces on $S$. foliosa in the marshes of southern and Baja California (Wilson 1982, Denno et al. 1987). 


\section{Habitats and growth forms of cordgrass}

S. alterniflora dominates the vegetation of many Atlantic, Gulf, and Pacific intertidal marshes, often occurring in extensive, pure stands (Adams 1963, Redfield 1972, Duncan 1974, Turner and Gosselink 1975, Kirby and Gosselink 1976, Aberle 1990). S. alterniflora is restricted to the intertidal zone ranging from $\approx$ Mean High Water level (MHW) to elevations as much as.2 m below MHW (Blum 1968, Redfield 1972). Along this elevational gradient, this grass characteristically occurs in two growth forms (Miller and Egler 1950, Teal 1962, Adams 1963, Redfield 1972, Hatcher and Mann 1975, Turner 1976, Denno and Grissell 1979, Ornes and Kaplan 1989). Tall-form plants (1-2 $\mathrm{m}$ in height) grow in low-marsh habitats along the depressed banks of tidal creeks, along bay edges, and occasionally as isolated stands on low tidal flats (Redfield 1972). Further inland near MHW (hereafter the high marsh), short-form $S$. alterniflora grows as a dense bed of short rosettes in vast meadows, attaining heights of only 10$40 \mathrm{~cm}$ (Blum 1968, Redfield 1972). Many of the intertidal marshes along the Atlantic, Gulf, and Pacific coasts are characterized by expanses of short-form $S$. alterniflora on the high marsh, which abruptly intergrade into a fringe of tall-form plants bordering tidal creeks and bay edges (Adams 1963, Duncan 1974, Turner and Gosselink 1975, Kirby and Gosselink 1976, Turner 1976, Denno and Grissell 1979, Mendelsshon et al. 1981, Stout 1984, Daehler and Strong 1994).

There is an extensive literature concerning the genetic and environmental factors influencing the growth form of $S$. alterniflora (reviewed in Anderson and Treshow 1980). Nitrogen availability, salinity, sulfide level, and soil drainage are among the most commonly espoused environmental causes of growth-form variation (reviewed in Gallagher et al. 1988, Ornes and Kaplan 1989). Although genetic factors play some role (Gallagher et al. 1988), most evidence indicates that environmental factors are largely responsible for differences in growth form (Ornes and Kaplan 1989).

At most Pacific coast locations the structure of the Spartina foliosa marsh is not comparable to $S$. alterniflora marshes in that growth forms are not clearly distinguished (Zedler 1982, 1993, Zedler et al. 1992). Although $S$. foliosa occupies an elevational range from MHW to as much as $0.5 \mathrm{~m}$ below MHW (Ustin et al. 1982, Zedler 1982), it is typically limited to a narrow band of intertidal vegetation or isolated patches along the seaward edge of the marsh (Ustin et al. 1982, Zedler 1982, 1993, Zedler et al. 1992).

\section{Geographic variation in the disturbance and destruction of cordgrass habitats}

Regional differences in tidal range, tidal frequency, and winter severity influence the level of disturbance of Spartina habitats (Denno and Grissell 1979, Denno 1983). Several lines of evidence support the contention that regional variation in disturbance is greater for tallform than short-form Spartina.

Throughout much of the Atlantic coast, new shoots of both growth forms appear in spring, maximum live biomass is attained during summer or early fall, and plants begin to senesce in late fall (Blum 1968, Squiers and Good 1974, Denno and Grissell 1979). On the high marsh, the dead rosettes of short-form Spartina remain in place over winter and then decay during the course of the next season (Squiers and Good 1974). In stark contrast, the action of winter tidewaters, winds and shifting ice shear off the culms of tall-form plants leaving exposed creek banks often free of litter (Denno and Grissell 1979; Fig. 1A and B). The selective winter destruction of the tall-form Spartina habitat has been documented from Massachusetts to Georgia (Teal 1962, Blum 1968, Squiers and Good 1974, Denno and Grissell 1979, Niering and Warren 1980). Above $37^{\circ} \mathrm{N}$ latitude (north of North Carolina), no living aboveground biomass of Spartina overwinters in either the streamside or high-marsh habitats (Turner 1976).

In addition to differences in winter destruction, tidal inundation also varies markedly between the major Spartina habitats along the Atlantic coast. For example, short-form plants in Massachusetts are flooded only $6 \%$ of the time compared to $55 \%$ for tall-form plants (Redfield 1972). Furthermore, streamside plants on the Atlantic coast do not grow tall enough to escape significant tidal inundation until spring or early summer, at which time they become available for exploitation by herbivorous insects (Denno and Grissell 1979).

The growth dynamics and winter disturbance of Spartina on the Gulf coast contrasts with that along the Atlantic coast (Kurz and Wagner 1957, Turner 1976, Denno and Grissell 1979, Stout 1984). The mild climate allows living shoots of both tall-form and shortform plants to persist throughout winter and promotes year-round growth (Kirby and Gosselink 1976, Turner 1976). Maximum live biomass occurs in early fall, after which aboveground portions of plants begin to senesce, but the understory of new shoots continues to grow (Kirby and Gosselink 1976). Destruction of low-marsh habitats along the Gulf coast is minimal due to reduced tidal range (Tide Tables 1992), an absence of ice, and reduced frequency of tidal submergence during winter (Kirby and Gosselink 1976, Denno and Grissell 1979; Fig. 1C and D). The large amounts of litter or standing dead vegetation on Gulf marshes during winter provide further evidence for reduced tidal disturbance along the Gulf (Kirby and Gosselink 1976, Denno and Grissell 1979). Nevertheless, even along the Gulf coast during winter and early spring when regrowth is short, vegetation in the lowest portion of the tidal range can incur significant inundation (Antolin and Strong 1987, Throckmorton 1989).

Although less extreme than along the Atlantic coast, there is evidence for an elevational gradient in the disturbance of Spartina foliosa occupying the Pacific 
A

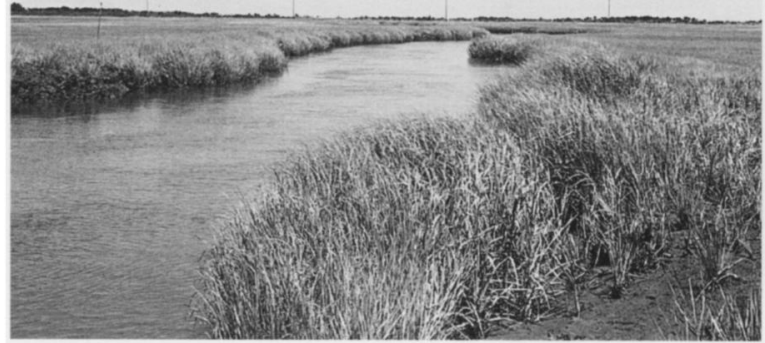

c

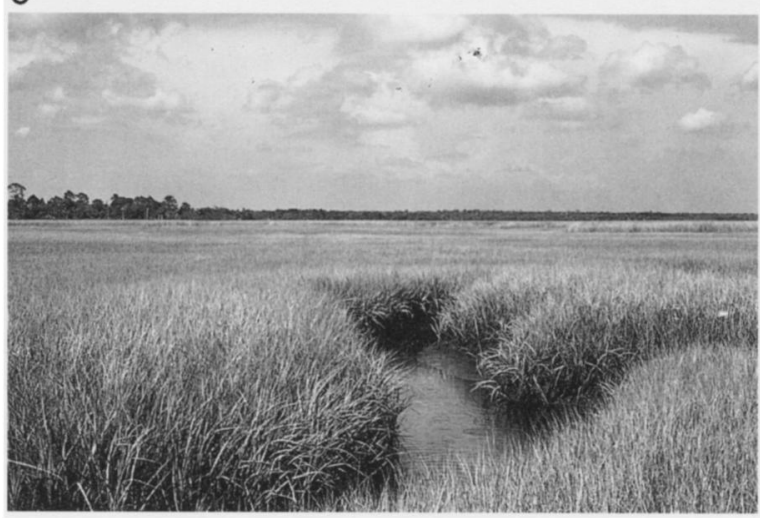

B

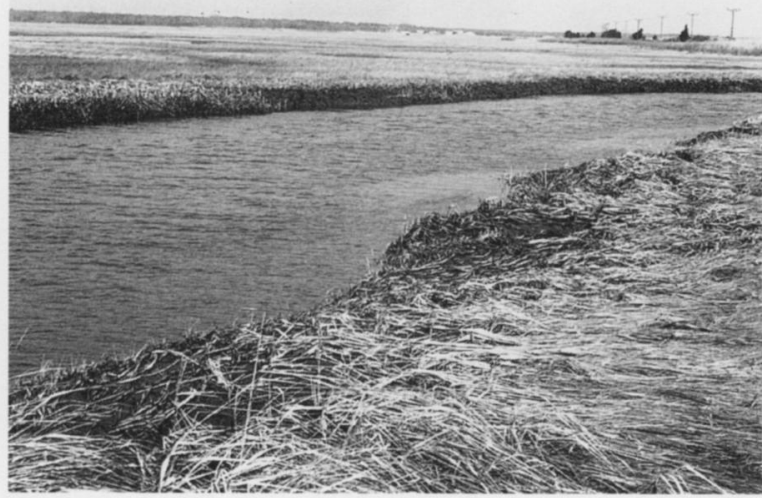

D

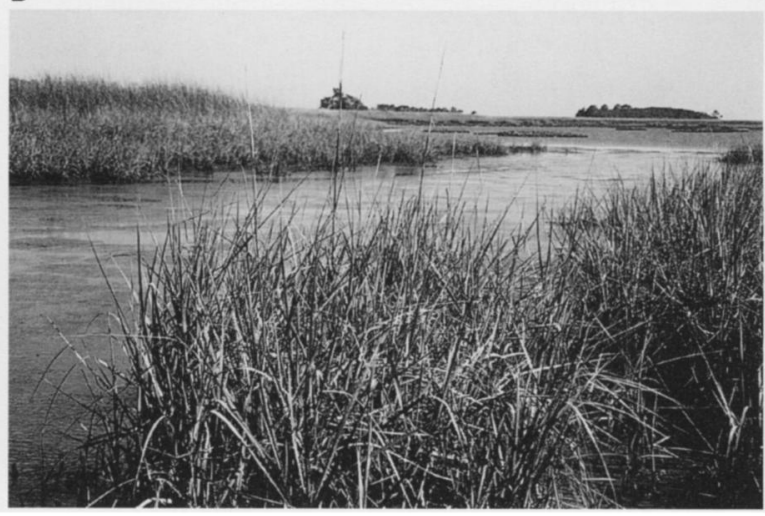

FIG. 1. Comparative seasonal destruction of tall-form Spartina alterniflora growing on stream banks in Atlantic and Gulf coast intertidal marshes. (A) Robust, tall-form plants $(>1 \mathrm{~m}$ in height) during summer at Tuckerton, New Jersey, senesce during late fall and are destroyed during winter by storms and shifting ice leaving, (B) bare creekbanks unsuitable as overwintering habitats for planthoppers. (C) During summer, plants also grow tall along the tidal creeks in the low marsh at Cedar Key, on the Gulf coast of Florida. (D) In contrast to Atlantic locations, senescing culms remain standing through winter along the Gulf, have associated with them an understory of regrowth, incur no ice scouring, and provide a habitat in which planthoppers can persist through winter.

marshes of the San Francisco Bay area. In these marshes where mean tidal range is moderate (Tide Tables 1993), living shoots are not evident during winter in many low-marsh habitats, but do persist throughout the year on the high marsh (Ustin et al. 1982, Roderick 1987). In contrast, on southern California and Baja California marshes, mean tidal range is comparatively less (Tide Tables 1993), frost is rare, and the mediterranean-like climate promotes year-round growth of $S$. foliosa (Neuenschwander et al. 1979, Zedler 1982, 1993, Zedler et al. 1992).

\section{Life history of saltmarsh planthoppers}

Both nymphs (five instars) and adults of $P$. marginata and $P$. dolus feed on the phloem sap of their hosts from the upper surface of the leaves (Denno et al. 1987, Cook and Denno 1994). Along the central Atlantic coast both planthoppers are trivoltine and adults are absent from the marsh from November through March (Denno et al. 1987). On the Gulf coast, both species are multivoltine and reproduction occurs year-round (Denno and Grissell 1979, Denno 1983, Strong and
Stiling 1983; Denno et al. 1987). P. marginata is trivoltine in the San Francisco Bay area marshes with adults absent from December through February (Roderick 1987). In southern California and Mexico, adults of $P$. dolus are present throughout the year and the species breeds continuously (Johnson 1991; R. F. Denno, personal observation).

In New Jersey, both species overwinter on the high marsh as active nymphs nestled in litter (Denno et al. 1987), as does $P$. marginata on northern California marshes (Roderick 1987). Experimental evidence indicates that litter is critical for winter survival on the high marsh (Tallamy and Denno 1979). In contrast, nymphs do not survive the winter in low-marsh habitats in either New Jersey or northern California populations (Denno and Grissell 1979, Roderick 1987). Because females of both species insert their eggs exclusively in living leaf blades (Denno et al. 1987, Denno 1994b), eggs are unable to persist in habitats free of living culms. All stages of Prokelisia planthoppers, including adults, are able to withstand short-term tidal inundation 
(Vince et al. 1981, Roderick 1987, Throckmorton 1989).

\author{
Wing dimorphism, dispersal \\ capability, and planthopper habitats
}

Adults of both Prokelisia species are wing dimorphic; both fully-winged individuals (macropters) and adults with reduced wings (brachypters) occur in most populations (Wilson 1982, Denno et al. 1985, 1987, Denno 1994b). Macropters are capable of long-distance flight $(>30 \mathrm{~km}$ ) (Denno and Grissell 1979, Denno 1983, Sparks et al. 1986, Antolin and Strong 1987, Roderick 1987), whereas brachypters move only short distances of several metres by walking or jumping (Denno and Grissell 1979, Denno et al. 1985, Denno 1994b). Brachypters reproduce at a significantly earlier age and are more fecund than macropters (Denno et al. 1989, Denno 1994b).

Wing form in Prokelisia planthoppers is determined by a developmental switch that responds to environmental cues (Denno et al. 1985, 1991, Roderick 1987, Denno and Roderick 1992). The sensitivity of the switch is heritable and under polygenic control (Roderick 1987, Denno and Roderick 1990, Denno 1994b). Of the environmental factors known to affect wing form in Prokelisia planthoppers, population density is by far the most significant (Denno et al. 1985). The production of macropters is positively density dependent in both species (Denno et al. 1985, Denno and Roderick 1992).

Data from one New Jersey population suggest that the primary habitat for development differs between $P$. marginata and $P$. dolus. For $P$. marginata, densitydependent dispersal results in interhabitat movements between overwintering habitats on the high marsh (short-form meadows of Spartina) and summer sites for development in the low marsh (stands of tall-form Spartina) (Denno and Grissell 1979, Denno et al. 1985). By contrast, $P$. dolus is a much more sedentary species, which appears to both overwinter and develop on the high marsh (Denno et al. 1987). However, it has not been established whether this difference in habitat selection between the two species is consistent throughout their range in North America.

Geographic variation in the dispersal capability of Prokelisia planthoppers has been suggested on the basis of studies at a few locations on the Atlantic and Gulf coasts (Denno and Grissell 1979, McCoy and Rey 1981, Wilson 1982, Strong and Stiling 1983). For example, the incidence of macroptery in one New Jersey population of $P$. marginata is much higher $(>80 \%)$ than that reported for two neighboring Florida populations on the Gulf $(<10 \%)$ (Denno and Grissell 1979, Strong and Stiling 1983, Denno et al. 1987). However, broad-scale variation in wing-form composition and its underlying cause has not been thoroughly documented for either species.

\section{Hypotheses Concerning Habitat PERSISTENCE AND DisPersal}

For Prokelisia planthoppers, habitat persistence is probably determined in large part by three interacting factors: winter severity, tidal disturbance, and marsh elevation. Due to enormous regional differences in the selective destruction and disturbance of the low-marsh habitat during winter (Teal 1962, Blum 1968, Squiers and Good 1974, Kirby and Gosselink 1976, Turner 1976, Niering and Warren 1980, Stout 1984), lowmarsh inhabitants should face much greater geographic variability in habitat persistence than high-marsh occupants. In particular, in regions where low-marsh habitats are destroyed or disturbed during winter (Atlantic and Pacific coasts), exploitation of these habitats must depend on annual recolonization events. Such recolonization is probably much less critical for the exploitation of either low-marsh habitats in regions with minimal winter disturbance (Gulf coast), or high-marsh habitats, which incur little disturbance in any region.

We hypothesize that in regions where planthoppers fail to remain through winter in their primary developmental habitat, high levels of dispersal capability (\% macroptery) will be evident. Conversely, we predict low levels of macroptery in association with high levels of endurance through winter in the habitat where most development occurs. Limited data suggest that $P$. marginata is a low-marsh inhabitant, whereas $P$. dolus resides mostly on the high marsh (Denno and Grissell 1979, Denno et al. 1987). Thus, we predict that $P$. marginata will exhibit regional variation in levels of dispersal that parallels regional variation in low-marsh disturbance. We also predict that $P$. dolus will exhibit minimal variation in levels of dispersal due to the low levels of disturbance of the high marsh across all regions. We test these predictions concerning habitat persistence and dispersal by: (1) examining regional patterns of low-marsh and high-marsh occupancy by the Prokelisia species and assessing their ability to remain in their primary habitat for development yearround, (2) detailing intraspecific variation in dispersal capability (percent macroptery) within and among regions, and (3) correlating variation in dispersal capability with variation in habitat persistence, as measured by the ability of planthoppers to remain throughout the year in their primary developmental habitat.

In addition, we hypothesize that regional differences in dispersal capability are genetically based. We test this hypothesis by determining the wing-form response of Atlantic and Gulf coast populations of both Prokelisia species across a range of representative densities. Population differences in the frequency of macropter production at a common high density would be consistent with our hypothesis regarding genetic differences among populations. 


\section{METHODS}

\section{Primary developmental habitats of planthoppers and their suitability for year-round occupancy}

To determine the primary habitat for development of both Prokelisia species and to assess how well each species endures throughout the year in that habitat, we examined in detail the year-round patterns of highmarsh and low-marsh exploitation by the two Prokelisia species at one Atlantic coast location (Tuckerton, Ocean County, New Jersey). To examine these issues at a regional scale, we compared warm-season and cold-season patterns of low-marsh and high-marsh occupancy by populations on the Atlantic coast (a region experiencing extensive winter disturbance of the low marsh) and the Gulf coast (a region incurring much less winter disturbance).

Patterns of habitat occupation at Tuckerton, New Jersey were determined by sampling Prokelisia planthoppers in both low-marsh (tall-form) and high-marsh (short-form) habitats on six dates throughout the year (9 May, 23 May, 6 June, 17 July, 28 August, and 25 September, 1986). Eight pairs of plots $\left(100 \mathrm{~m}^{2}\right)$ were established with one plot of the pair in each habitat type. Planthoppers were sampled using a D-Vac suction sampler with a $0.093-\mathrm{m}^{2}$ sampling head. All plots were sampled once on each date, and each sample consisted of 1630 -s placements of the sampling head over the Spartina vegetation (see Denno et al. 1980 for details). For each Prokelisia species the proportion of the population occupying the low-marsh habitat (no. conspecifics in low-marsh Spartina/no. conspecifics in lowmarsh + high-marsh Spartina) was determined from each plot pair. The effect of species ( $P$. marginata and $P$. dolus), date, and their interaction on the angulartransformed proportion of adult planthoppers in the low-marsh habitat was assessed with repeated-measures ANOVA (SAS 1990). Failure to remain in one habitat year-round would be suggested by a significant effect of date and/or a significant date by species interaction, whereby one or both species shifts its distribution from one habitat to the other.

We also determined at a regional scale the primary habitat for development of both Prokelisia species, and the ability of each species to endure throughout the year in that habitat. To do so, we compared warmseason and cold-season patterns of low-marsh (tallform) vs. high-marsh (short-form) occupancy between populations on the Atlantic coast and the Gulf coast. For each geographic location, the proportion of both $P$. marginata and $P$. dolus occupying the low-marsh habitat was determined from the pooled totals of adults from three sweep-net samples (one sample $=25$ sweeps with a $36 \mathrm{~cm}$ diameter net) (see Appendix for locations and sample sizes). To determine seasonal differences in habitat occupation between regions, samples were divided into: (1) warm-season samples (late spring, summer, and fall), and (2) cold-season samples (winter or immediately after winter). These temporal categories were explicitly established in order to assess habitat occupation during the cold season when low-marsh disturbance is maximal and planthoppers have not yet undergone spring migration, as well as during the warm season after such migrations to the low marsh have occurred (see Denno 1983, Denno et al. 1985, 1986, Antolin and Strong 1987). The effect of region (Atlantic and Gulf), season (warm and cold), species ( $P$. marginata and $P$. dolus), and their interaction on the angular-transformed proportion of adult planthoppers in the low-marsh habitat was assessed using ANOVA and specific means were compared using Sidak's adjustment for multiple comparisons (SAS 1990). A regional difference in planthopper endurance in the low marsh would be indicated by a significant region by season interaction in which the proportion of the population in the low marsh declines more during the cold season in one region than the other. The Pacific coast region was excluded from this analysis because we were unable to obtain a sufficient number of cold-season samples (northern California), and because the distinction between high-marsh and low-marsh habitats is often ambiguous on southern California marshes due to the small patch size of Spartina and its rather homogeneous growth form.

\section{Geographic variation in the dispersal capability of planthoppers}

To detail geographic variation in the dispersal capability of both $P$. marginata and $P$. dolus, we sampled planthoppers from 112 locations along the Atlantic, Gulf, and Pacific coasts (see Appendix for locations and sample dates). At each location, three sweep-net samples were taken in both low-marsh (tall-form Spartina) and high-marsh habitats (short-form Spartina). Sweep samples of planthoppers were placed in ethyl alcohol (95\%) and returned to the lab for censusing. Subsequently, all planthoppers in each sample were sorted by species and wing form and counted.

The dispersal capability of the Prokelisia species at each geographic location was estimated by determining the percentage of macropters (no. macropters/[no. macropters + brachypters]) in pooled samples of all conspecific adults from all habitats. The effects of region (Atlantic, Gulf, and Pacific), Prokelisia species, and their interaction on macroptery (angular-transformed percentage) were determined using ANOVA and means were compared using Sidak's adjustment for multiple comparisons (SAS 1990). For each species, a site was included in this analysis only if 25 or more adults of that species were obtained from the pooled samples. For $P$. marginata, 13, 20, and 28 sites were included, and for $P$. dolus, 8,23 , and 53 sites were available from the Pacific, Gulf, and Atlantic coasts, respectively (see Appendix). 


\section{Relationship between habitat persistence and dispersal capability}

To test the hypothesis that levels of dispersal increase with decreasing habitat persistence, we determined the relationship between the dispersal capability (percent macroptery) of Prokelisia planthoppers and their ability to endure through winter in their primary habitat for development. We reasoned that in regions where planthoppers fail to endure through winter in their primary habitat for development, high levels of dispersal capability (percent macroptery) should be evident in order to facilitate the recolonization of this habitat from overwintering sites. As an index of habitat persistence for each species, we determined the proportion of that species' population occupying the primary habitat for development (low marsh for $P$. marginata and high marsh for $P$. dolus) during or just following winter. For example, a small proportion of a $P$. marginata population in the low marsh (relative to the high marsh) just after winter, would be indicative of poor persistence of the low marsh habitat. As above, this mean proportion was calculated from the pooled sum of three sweep samples taken in both low-marsh and high-marsh habitats at each location. This proportion was then regressed against the level of macroptery (percent) observed in the field during the growing season (late spring through fall) for $P$. marginata and for the two Prokelisia species combined. In all, data from 17 locations were available for analysis, 9 for $P$. marginata (5 Atlantic, 3 Gulf, and 1 Pacific) and 8 for $P$. dolus (5 Atlantic and 3 Gulf) (see Appendix). Data for the one Pacific coast population of $P$. marginata were taken from Roderick (1987).

\section{Evidence that regional differences in dispersal capability are genetically based}

To investigate a possible genetic basis for the regional differences in dispersal capability (percent macroptery) observed in field populations of both Prokelisia species, we raised individuals from one Atlantic and one Gulf coast population across the same range of densities in the laboratory and compared their density-wing form responses. The density-wing form response was compared between $P$. marginata populations from Tuckerton, New Jersey and Cedar Key, Florida, and between $P$. dolus populations from Tuckerton, New Jersey and East Tampa, Florida.

Plants containing eggs from East Tampa ( $P$. dolus), Cedar Key ( $P$. marginata) and Tuckerton (both species) were transplanted into pots on 20 May, 31 May, and 20 July 1987, respectively. First-instar nymphs hatching from these eggs were used to establish three conspecific density treatments $(3,11$, and 40 nymphs/tube cage) on Spartina seedlings, representing the naturally occurring range of densities in the field (Denno and Roderick 1992) (see Denno et al. 1985 for details on Spartina culture). The density treatments of 3,11 , and

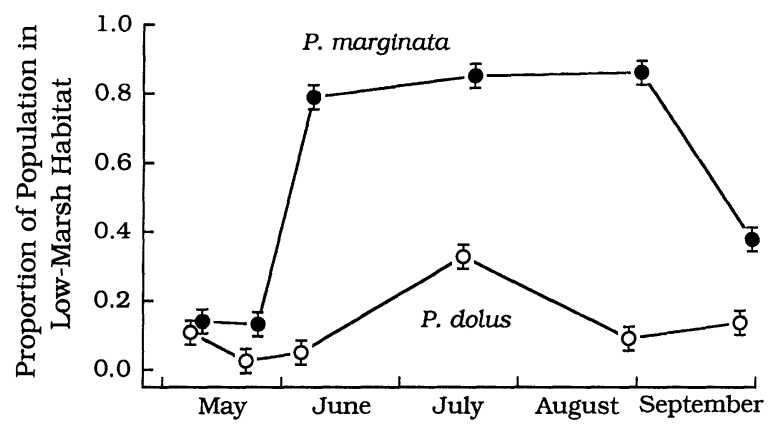

FIG. 2. Seasonal patterns of low-marsh occupation (proportion of population in low marsh compared to high marsh) by Prokelisia marginata and $P$. dolus at Tuckerton, New Jersey (1986), a site where destruction of the low-marsh habitat occurs annually during winter (Fig. 1B). Note the shift in the population of $P$. marginata from the high marsh (overwintering habitat) to the low marsh (primary habitat for development) in May, and then back to the high marsh in fall. The population shift results from interhabitat dispersal. In contrast, $P$. dolus overwinters on the high marsh and remains there throughout the year. Means \pm 1 SE are shown.

40 , were replicated 25,20 , and 15 times, respectively. Caged seedlings from all experiments were maintained in incubators at $24 \pm 2^{\circ} \mathrm{C}$ in a $14: 10$ light-dark cycle. As adults emerged, their wing form was determined. The effects of population (Gulf and Atlantic), rearing density (3, 11, and 40), and their interaction on macroptery (percent) were determined using ANOVA, and means were compared using Sidak's adjustment for multiple comparisons (SAS 1990).

Because the eggs used in this experiment were taken from a largely macropterous population in New Jersey and a primarily brachypterous population in Florida, it could be argued that maternal effects might contribute to any observed differences in wing form between populations. However, for several planthopper species, including $P$. marginata, there is no clear relationship between the wing form of parents and offspring (Kisimoto 1965, Raatikainen 1967, Roderick 1987), suggesting that such maternal effects are minimal or nonexistent.

\section{RESULTS}

\section{Primary developmental habitats of planthoppers and their suitability for year-round occupancy}

Seasonal patterns of low-marsh and high-marsh occupation by the two Prokelisia species were assessed in detail at Tuckerton, New Jersey, where destruction of the low-marsh habitat occurs annually during winter (Fig. 1B). Following winter in early May, most of the population of both species $(\approx 90 \%)$ occurred on the high marsh (Fig. 2). The small fraction of adults sampled in the low marsh at this time $(10 \%$ of the population) was probably an overestimate, due to the difficulty of timing the sample after nymphs begin molting to adults yet before those adults engage in spring migration (see Denno et al. 1987). Despite their co-oc- 
currence on the marsh during winter and early spring, the two species exhibited very different patterns of habitat exploitation during summer and fall. During this time, $>80 \%$ of the $P$. marginata population occurred in the low-marsh habitat, whereas a mere $20 \%$ of the $P$. dolus population occupied the low marsh. The shift in the distribution of the $P$. marginata population from the high to the low marsh in June corresponds with the period of spring-summer migration for this species (Denno et al. 1985, 1986, Denno 1994b). During fall, the decline in the proportion of the $P$. marginata population in the low-marsh habitat is associated with the emigration of macropterous adults from tallform Spartina and their colonization of high-marsh habitats prior to the onset of winter (Denno 1983). Thus, $P$. marginata selectively exploits the low-marsh habitat for development during the summer and fall, and $P$. dolus remains mostly on the high marsh, its primary habitat for development, throughout the year. These differences in habitat occupancy are supported by a significant species effect $\left(F_{1,14}=171.4 ; P<\right.$ $0.001)$, date effect $\left(F_{5,70}=56.4 ; P<0.001\right)$, and species by date interaction $\left(F_{5,70}=27.1 ; P<0.001\right)$ on the proportion of the adult population inhabiting the low-marsh habitat.

Habitat exploitation in the two Prokelisia species was also determined at a much larger geographic scale by comparing warm and cold season patterns of low-marsh and high-marsh occupancy between the Atlantic coast and the Gulf coast (Fig. 3). Regardless of region, the proportion of the $P$. marginata population inhabiting the low marsh was significantly higher than that for $P$. dolus $\left(F_{1,87}^{\text {Species }}=36.92, P<0.001 ; F^{\text {Species } \times \text { Region }_{1,87}}=2.26\right.$, $P=0.14)$. This pattern corroborates that the difference between the species in their primary habitat for development, which we detailed in New Jersey, also occurs over a broad geographic scale.

For $P$. marginata, the proportion of the population in the low marsh during the warm season was high in both Atlantic (64\%) and Gulf coast regions (72\%) (Fig. 3 ). During the cold season, however, the proportion of the population remaining in the low marsh plummeted to $7 \%$ on Atlantic marshes, but only dropped to $40 \%$ in Gulf coast marshes. These data demonstrate that $P$. marginata is better able to endure winter conditions on the low marsh along the Gulf compared to the Atlantic coast. In contrast, $P$. dolus showed only a slight shift of the population from the high marsh to the low marsh during the warm season along the Atlantic, but exhibited no such shift along the Gulf coast (Fig. 3). However, along both coasts, only a small proportion of $P$. dolus populations ( $<20 \%$; Fig. 3 ) occurred on the low marsh during either season. The difference between the two species in their warm-season and cold-season occupancy of the low-marsh habitat was statistically significant $\left(F^{\text {Season }}{ }_{1,87}=35.03, P<0.001 ; F^{\text {Species } \times \text { Season }_{1,87}}\right.$ $=8.98, P=0.004)$. Moreover, the seasonal disparity in the occupancy of the low marsh was significantly
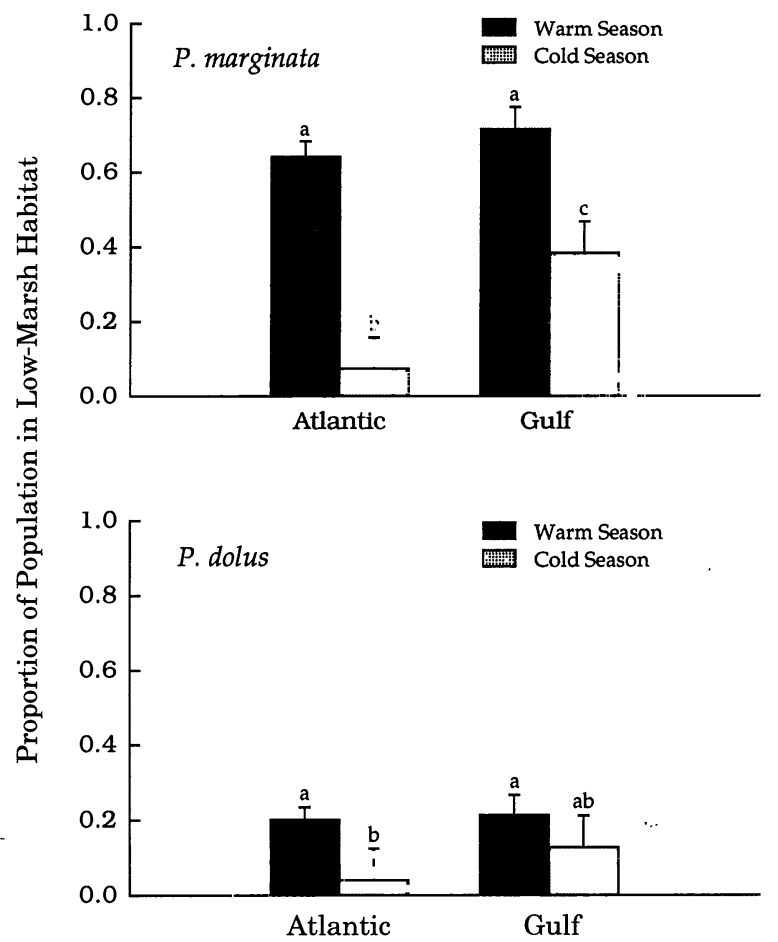

FIG. 3. Warm and cold seasonal patterns of low-marsh occupancy (proportion of population in low marsh compared to high marsh) by Prokelisia marginata and $P$. dolus at sites along the Atlantic where low-marsh habitats are destroyed during winter, and at locations along the Gulf coast where low-marsh habitats are less disturbed during winter (see Appendix for specific locations). Note that for $P$. marginata (top), the proportion of the population remaining through the cold season in the low marsh is much lower for Atlantic than Gulf coast locations, yet during the warm season most individuals occupy the low marsh on both coasts. In contrast, the proportion of the $P$. dolus population in the low marsh (bottom) remains low during both seasons. Means with different letters are significantly different $(P<0.05$, ANOVA followed by Sidak's adjustment for multiple comparisons).

greater along the Atlantic than the Gulf coast $\left(F^{\text {Region }}{ }_{1,87}\right.$ $\left.=7.64, P=0.007 ; F^{\text {Region } \times \text { Season }}{ }_{1,87}=6.07, P=0.047\right)$.

\section{Geographic variation in the dispersal capability of planthoppers}

Our survey revealed significant geographic variation in dispersal capability (percent macroptery) of both $P$. marginata and $P$. dolus, but the effect of region on macroptery differed between the two species $\left(F^{\text {Region }}{ }_{2,140}=101.7, P<0.001 ; F^{\text {Species }}{ }_{1,140}=231.6\right.$, $P<0.001 ; F^{\text {Region } \times \text { Species }}{ }_{2,140}=76.3, P<0.001 ;$ Figs. 4-6). Populations of $P$. marginata with the greatest capacity for dispersal occurred along the Atlantic coast $(92 \pm 2 \%$ macroptery, mean $\pm 1 \mathrm{SE}$ ), followed by Pacific populations ( $29 \pm 4 \%$ ), and then Gulf populations $(17 \pm 5 \%$ ) (all means differ, $P<0.01$; Figs. 4 and 6). Overall, the dispersal capability of $P$. dolus was much less than that for $P$. marginata, with levels of macroptery significantly higher in both Atlantic ( 8 
Prokelisia marginata

$\%$ Macroptery D \% Brachyptery

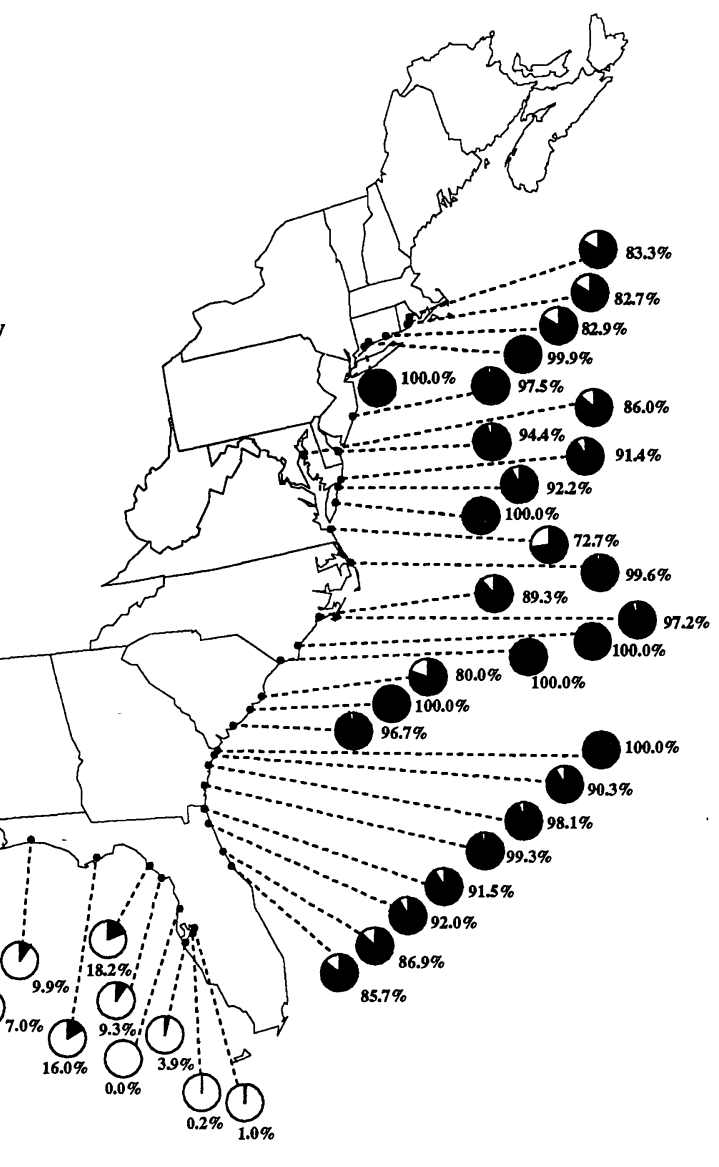

FIG. 4. Geographic variation in the dispersal capability (percentage macroptery) of Atlantic and Gulf coast populations of Prokelisia marginata (see Appendix for specific locations). Atlantic populations are much more macropterous than Gulf coast populations.

$\pm 2 \%)$ and Gulf coast populations $(6 \pm 2 \%)$ than in Pacific coast populations $(0.2 \pm 0.1 \% ; P<0.03$; Figs. 5 and 6).

Within regions, levels of macroptery remained rather constant (Figs. 4-6). There were a few notable exceptions to intra-regional constancy in macroptery. Higher-than-average levels of macroptery were observed in a few Texas and Louisiana populations of $P$. marginata and $P$. dolus (Figs. 4 and 5) as well as in a few midAtlantic populations of $P$. dolus (Fig. 5). In two of these cases (64\% macroptery in an eastern Texas population of $P$. marginata, and $84 \%$ in a Maryland population of $P$. dolus), we observed the aerial dispersal of macropters under population outbreak conditions.

\section{Relationship between habitat persistence and dispersal capability}

The level of macroptery (percent) was inversely related to habitat persistence (indexed as the proportion of each species' population able to endure through winter in the primary habitat for development), when only populations of $P$. marginata were considered in the analysis $\left(Y^{\text {Macroptery }}=99.7-148.7 X, R^{2}=0.76, P=\right.$
0.001 ), and when populations of both species were pooled for analysis $\left(Y^{\text {Macroptery }}=89.8-90.8 X, R^{2}=\right.$ $0.75, P=0.001$ ) (Fig. 7). At Atlantic and Pacific locations, the proportion of the $P$. marginata population remaining through winter in the primary habitat for development (low marsh) was low $(<20 \%)$, and associated levels of macroptery during the growing season were high $(>75 \%)$. In contrast, the proportion of the $P$. marginata population remaining through winter in the low marsh on the Gulf was high (30-70\%), and associated levels of macroptery were low $(<15 \%)$. The proportion of $P$. dolus populations remaining through winter in their primary habitat for development (high marsh) was high $(>70 \%)$ at all locations along the Atlantic coast and levels of macroptery were low $(<35 \%)$. These results suggest that along the Atlantic and Pacific coasts, large-scale dispersal is necessary for $P$. marginata to recolonize the low marsh, a habitat that is unsuitable for winter survival in these regions. In contrast, the low levels of macroptery in most Gulf coast populations of $P$. marginata apparently reflect the ability of this species to remain on the low marsh year-round in this equitable region. 


\section{Prokelisia dolus}

$\%$ Macroptery $\%$ Brachyptery

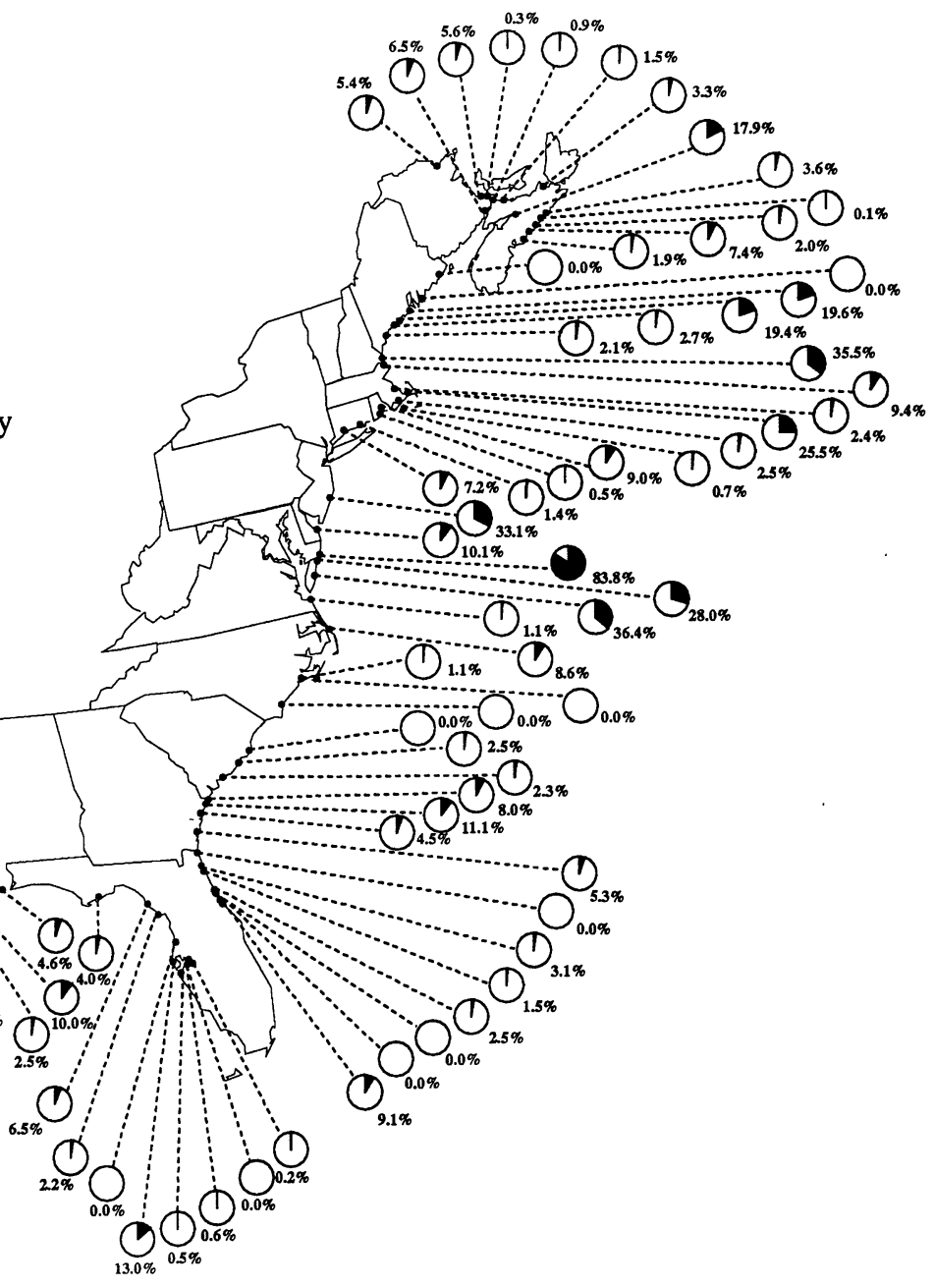

FIG. 5. Geographic variation in the dispersal capability (percentage macroptery) of Atlantic and Gulf coast populations of Prokelisia dolus (see Appendix for specific locations). Levels of macroptery are similarly low in both Atlantic and Gulf coast populations.

Low levels of dispersal occur in all populations of $P$. dolus, a species that remains throughout the year in its primary habitat for development on the less-disturbed high marsh.

\section{Evidence that regional differences in dispersal capability are genetically based}

New Jersey and Florida (Gulf) populations of both Prokelisia species differed dramatically in their tendency to produce macropters (Fig. 8). For the two populations of $P$. marginata, more adults molted into macropters as rearing density increased, but the overall level of macroptery (percent) was much higher in the New Jersey population across all rearing densities $\left(F^{\text {Density }}{ }_{2,103}=38.96, P<0.001 ; F^{\text {Population }_{1,103}}=76.51\right.$,

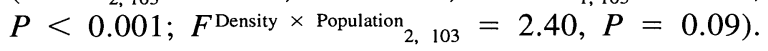
Similarly, macroptery (percent) increased with crowding in both populations of $P$. dolus, but this response was significantly higher in the New Jersey population than the Florida population (Fig. $8 ; F^{\text {Density }}{ }_{2,93}=12.60$, $P<0.001 ; F_{\text {Population }_{1,93}}=85.04, P<0.001$; $\left.F_{\text {Density } \times \text { Population }}{ }_{2,93}=0.76, P=0.47\right)$.

These data suggest that selection for dispersal capability has acted differentially in these Atlantic and Gulf coast populations, resulting in a greater production of macropters at a given density in the New Jersey populations of both Prokelisia species. Not surprisingly, these density-wing form responses paralleled the incidence of macroptery observed in the field. For $P$. marginata, field levels of macroptery were $98 \%$ for the New Jersey population and 9\% for the Florida population. Similarly, for $P$. dolus, field levels of macroptery were $33 \%$ and $0.6 \%$ for the New Jersey and Florida populations, respectively. Thus, interregional variation in macroptery observed in field populations of the Prokelisia planthoppers (Figs. 4-6) apparently reflects genetically based differences in dispersal capability. 


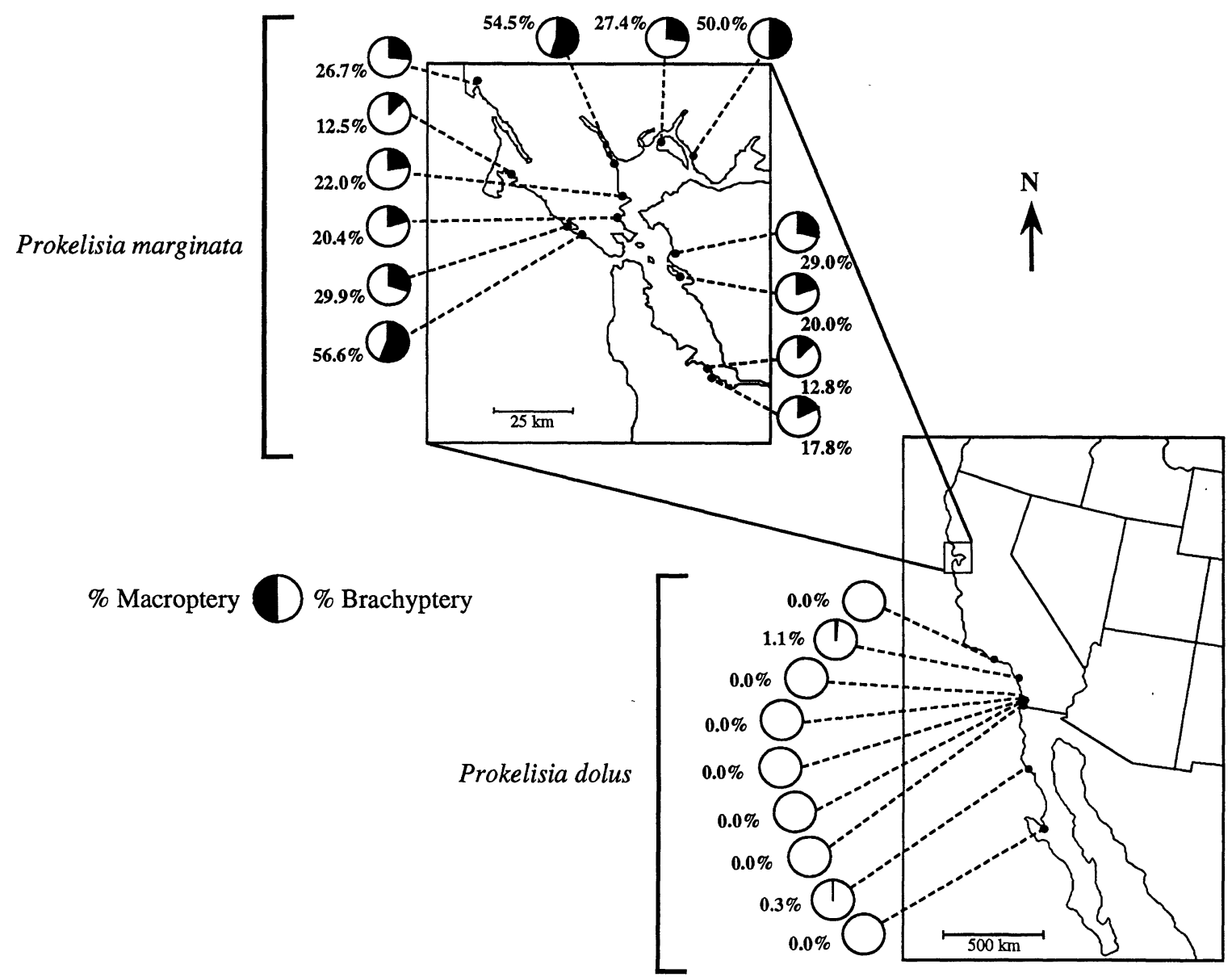

FIG. 6. Geographic variation in the dispersal capability (percentage macroptery) of Pacific coast populations of Prokelisia marginata in the San Francisco Bay area of California, and P. dolus in southern and Baja California (see Appendix for specific locations).

\section{DISCUSSION}

Dispersal can be a vitally important life history trait for organisms that exploit spatially-variable habitats (Dingle 1985, Roff 1986b, 1990, Taylor and Karban 1986, Denno et al. 1991, Roff and Fairbairn 1991). Also, dispersal can stabilize population dynamics (Reddingius and den Boer 1970, Vance 1980, den Boer 1981, Hastings 1982, Roff 1986a, Denno and Peterson 1995), determine the nature of linkages within metapopulations (Ebenhard 1991, Hansson 1991, Harrison 1991), influence species interactions (Crowley 1981, Denno and Roderick 1992), and determine the genetic structure of populations (Slatkin 1985, Roderick 1996, Peterson and Denno, in press). Consequently, understanding those factors that influence the evolution and maintenance of dispersal is central to most of population biology.

Of those ecological factors influencing dispersal, habitat persistence is considered to be pivotal (Southwood 1962, 1977, Southwood et al. 1974, Harrison 1980, Brown 1986, Roff 1990). Although dispersal characters may be retained at low frequencies in per- sistent habitats if adults compete for limited resources (Hamilton and May 1977), or if winged individuals rarely fly (Fairbairn 1986, 1988, Roff 1986a), dispersal is essential for the tracking of changing resources in temporally and spatially heterogeneous environments (Roff 1974a, b, 1986a, Solbreck 1978, Leigh 1981). However, there is widespread evidence that dispersal entails significant costs, due both to the failure to find suitable habitats (Roff 1986a, Edwards and Sugg 1993) and to reduced reproduction resulting from energetic trade-offs with flight capability (reviewed in Roff 1986a, Denno et al. 1989, Roff and Fairbairn 1991). As a consequence of such phenotypic trade-offs, selection should act against dispersal in persistent habitats, and there should be an inverse relationship between habitat persistence and levels of dispersal (Roff 1990, Denno et al. 1991).

Rigorous tests of the habitat persistence-dispersal hypothesis, however, have been few and these are restricted for the most part to interspecific comparisons (see Roff 1990, Denno et al. 1991). To control for possible phylogenetic nonindependence, a preferred test 


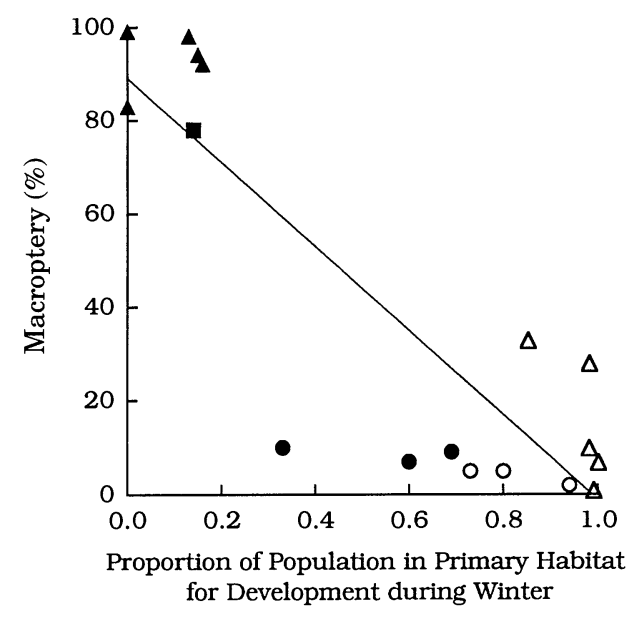

FIG. 7. Relationship between the level of macroptery (percentage) observed in field populations of Prokelisia planthoppers and the proportion of each species' population enduring through winter in the primary habitat for development ( $\left.Y^{\text {Macroptery }}=89.8-90.8 X, R^{2}=0.75, P<0.001\right)$. Populations that endure poorly through winter in their primary habitat exhibit high levels of dispersal capability. P. marginata populations: Atlantic coast $(\boldsymbol{\Delta})$, Gulf coast $(\boldsymbol{O})$, and Pacific coast (ם). $P$. dolus populations: Atlantic coast $(\triangle)$ and Gulf coast (O). See Appendix for specific locations.

of the hypothesis would be to assess the relationship between habitat persistence and dispersal among populations of the same species. Although population-level variation in dispersal capability has been documented for a number of insect species including planthoppers (Masaki 1973, Dingle 1978, Vepsäläinen 1978, Iwanaga et al. 1987, Roff 1990, Denno 1994b), such variation has never been directly linked to explicit measures of habitat persistence.

In this study, we detailed geographic variation in the dispersal capability (percent macroptery) of Prokelisia planthoppers throughout most of their geographic range. Several lines of evidence suggest that this variation in macroptery reflects variation in actual dispersal. First, macropters of Prokelisia are capable of long-distance flight $(>30 \mathrm{~km})$ (Denno and Grissell 1979, Sparks et al. 1986, Antolin and Strong 1987), whereas brachypters can walk or jump only a few metres (Denno and Grissell 1979, Denno et al. 1985, Denno 1994b). Second, macropters of Prokelisia are the only wing form to effectively colonize distant habitats (Antolin and Strong 1987, Denno and Roderick 1990, Denno 1994b). Furthermore, for other wing-dimorphic insects, both the flight threshold and the extent of wing muscle histolysis are negatively associated with the proportion of macropters in the population (Fairbairn 1986, Fairbairn and Desranleau 1987, Roff and Fairbairn 1991). Thus, the dispersal capability of macropters should be reduced for populations or species in which the proportion of macroptery is low. Whether this is the case for Prokelisia is not known. Nonetheless, the clear association between macroptery and dis-
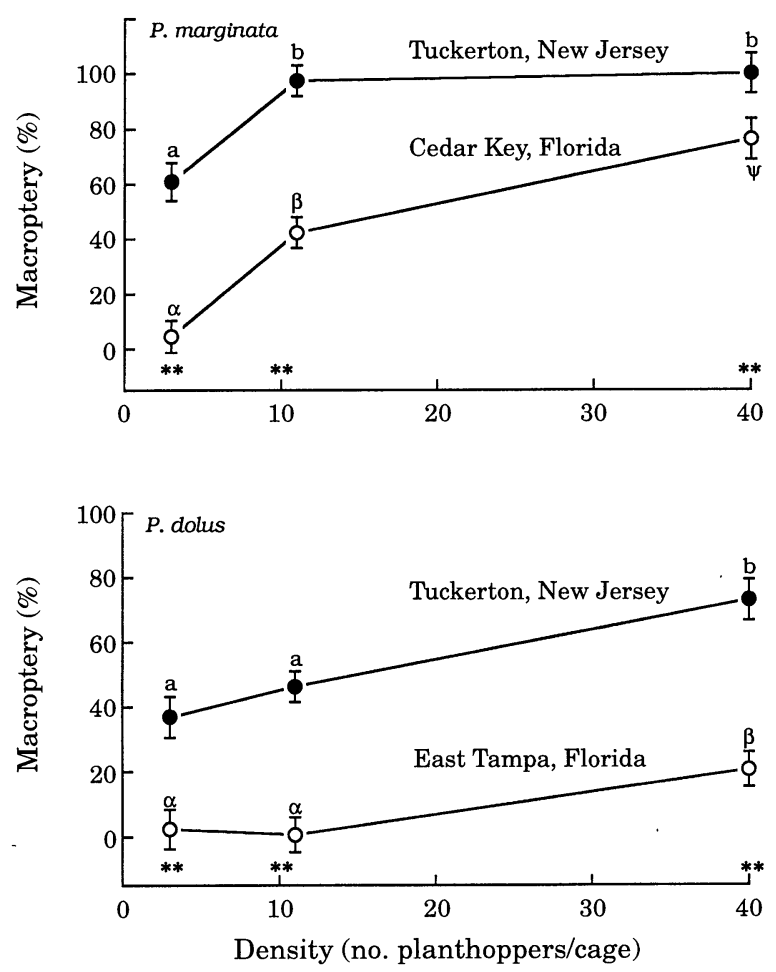

FIG. 8. Effect of rearing density on the production of macropters (percentage) in Atlantic and Gulf coast populations of Prokelisia marginata (top: Tuckerton, New Jersey and Cedar Key, Florida) and P. dolus (bottom: Tuckerton, New Jersey and East Tampa, Florida). Means ( \pm 1 SE) with different letters (Greek for Florida and Roman for New Jersey) are significantly different $(P<0.05)$. Significant differences between populations (within-density comparisons) are indicated along the abscissa $(* *=P<0.01$; ANOVA followed by Sidak's adjustment for multiple comparisons). Selection for dispersal capability has apparently acted differentially in these Atlantic and Gulf coast populations, resulting in greater production of macropters across all densities in the New Jersey populations of both Prokelisia species.

persal in Prokelisia planthoppers allowed us to use macroptery as a reliable index of dispersal for assessing the relationship between habitat persistence and dispersal.

The results of this study provide strong intraspecific support for the hypothesis that geographic variation in dispersal capability is inversely related to habitat persistence (Fig. 7). High levels of dispersal capability (92\% macroptery) in Atlantic coast populations of $P$. marginata are associated with this species' inability to remain through winter in the low marsh, its primary habitat for development. Conversely, low levels of dispersal (17\% macroptery) are affiliated with high endurance through winter in low-marsh habitats along the Gulf. There is widespread evidence in the literature that low-marsh habitats are severely disturbed by storms, tides, and shifting ice during winter along much of the Atlantic coast (Teal 1962, Blum 1968, Squiers and Good 1974, Denno and Grissell 1979, Niering and Warren 1980), providing an explanation for the failure of 
$P$. marginata to remain year-round in the low-marsh habitat in this region (Denno and Grissell 1979, Denno $1983,1988)$. A similar pattern prevails in northern California where intermediate levels of dispersal (29\% macroptery) occur in populations of $P$. marginata (Fig. 6). In this region, low-marsh habitats are perturbed to some degree during winter, low-marsh populations of planthoppers are reduced in this season, and interhabitat dispersal between high-marsh and low-marsh habitats occurs annually (Roderick 1987).

One might ask why there is so little variation in macroptery in populations of $P$. marginata along the entire Atlantic coast (Fig. 4), when the effects of ice scouring and the subsequent destruction of tall-form Spartina are much more severe to the north (Blum 1968, Squiers and Good 1974, Niering and Warren 1980). The answer lies in the multitude of factors that contribute to the ephemeral nature of the low-marsh habitat throughout this region. First, living culms of Spartina do not persist during winter in this habitat north of $37^{\circ} \mathrm{N}$ latitude (Turner 1976), leaving the lowmarsh habitat devoid of food and oviposition sites. Second, litter is selectively removed by tidewaters from this habitat during winter (Denno and Grissell 1979), and protective litter is needed for the successful overwintering of Prokelisia planthoppers (Tallamy and Denno 1979). Third, the tidal range is high along most of the Atlantic coast including locations far to the south in Florida and Georgia (Tide Tables 1992). Thus, even though living culms persist during winter along the Atlantic coast of the southern United States, they incur long periods of inundation, and do not grow tall enough for exploitation until later in spring (Denno and Grissell 1979). Consequently, although the window of opportunity for low-marsh occupancy is wider along the Atlantic coast from Florida to North Carolina, it nonetheless does close during winter and dispersal becomes a necessary strategy for the exploitation of this marsh habitat. Because high-marsh and low-marsh habitats are typically separated by distances greater than the ambit of brachypters (Denno et al. 1980, Denno 1994b), only macropters can colonize the low-marsh habitat in spring and escape it in fall before the onset of winter (Denno and Grissell 1979, Denno et al. 1980, Antolin and Strong 1987). Indeed, large accumulations of exclusively macropterous adults can be seen annually in spring as they colonize previously unoccupied patches of tall-form Spartina (Denno 1983, 1988).

Low-marsh habitats are far more persistent along the Gulf coast (Kurz and Wagner 1957, Turner 1976, Denno and Grissell 1979, Stout 1984), and P. marginata is much less prone to disperse in this region (Figs. 4 and 7). The equitable climate, lack of ice formation, year-round growth of Spartina, presence of litter, and reduced range and diurnal frequency of tides (Kirby and Gosselink 1976, Turner 1976, Denno and Grissell 1979) all undoubtedly contribute to the increased ability of $P$. marginata to remain through winter in low- marsh habitats. Yet, dispersal capability in P. marginata is not lost altogether in this region (Fig. 4). We do not argue that low-marsh habitats are altogether persistent along the Gulf, only that they are much more stable here than along the Atlantic coast. Indeed, populations of this species fail to survive during winter on the smallest of Spartina islets located in the lowest portion of the tidal range (Antolin and Strong 1987). However, we show that on average, $40 \%$ of $P$. marginata populations occur in the mainland strand of tallform Spartina habitats during winter (Fig. 3), and Antolin and Strong (1987) report successful overwintering on large Spartina islands as well. We contend that much lower levels of dispersal are required along the Gulf coast for $P$. marginata to exploit its primary, lowmarsh habitat. Nonetheless, spring bouts of dispersal by macropters do occur along the Gulf, resulting in the colonization of extirpated habitats in the lowest portion of the Spartina marsh (Antolin and Strong 1987).

Because $P$. dolus both develops and successfully overwinters primarily in the same habitat on the high marsh along the Atlantic and Gulf coasts (Figs. 2 and 3 ), dispersal by flight is not essential for most individuals to locate suitable host plants (Fig. 5). As a consequence of high habitat persistence, average levels of dispersal are similarly low in both the Atlantic (8\% macroptery) and Gulf coast regions (6\% macroptery). Nevertheless, dispersal is not lost completely in these regions. Under conditions of high population density, planthoppers induce nutritional changes in plants, causing them to deteriorate (Cagampang et al. 1974, Cook and Denno 1994). For P. dolus, heavy infestations alter the suitability of Spartina such that development rate is significantly prolonged in individuals subsequently raised on the same plants (R. F. Denno and J. Cheng, unpublished data). For planthoppers in general, the production of macropterous adults is intensified on deteriorating host plants (Kisimoto 1965, Denno et al. $1985,1994)$. Thus, conditions favoring the retention of dispersal capability may occasionally occur during population outbreaks on the high marsh. Indeed, one instance of mass aerial dispersal by $P$. dolus was observed at George Island Landing, Maryland during May 1988, in which an unusually high level of ambient macroptery $(84 \%)$ was coincident with an outbreak density (R. F. Denno, unpublished data). In the case of $P$. dolus, such population eruptions and accompanying large-scale dispersal events are very rare. During 19 yr of study at Tuckerton, New Jersey, we never observed a large-scale aerial dispersal of $P$. dolus, yet aerial dispersal is seen annually in $P$. marginata (Denno 1988, Denno et al. 1994). Nevertheless, these rare bouts of aerial dispersal by $P$. dolus may explain why dispersal ability is not sacrificed altogether, even though its habitats are for the most part persistent along the Atlantic and Gulf coasts.

Extremely low levels of dispersal ( $0.2 \%$ macroptery) are characteristic of $P$. dolus populations on the Pacific 
coast (Fig. 6). The frost-free climate, year-round growth of Spartina, and low tidal energy in southern and Baja California (Neuenschwander et al. 1979, Zedler 1982, 1993, Zedler et al. 1992) suggest that planthopper habitats there are persistent. The occurrence of high densities of $P$. dolus during "midwinter" in the only patches of Spartina present is consistent with the notion that habitats are persistent in this region (Appendix). However, it is difficult to argue that planthopper habitats are more persistent in this region than along the Gulf coast, where winters are no more harsh and tidal ranges are slightly less (Pearce and Smith 1990, Tide Tables 1992, 1993).

We suggest that the extremely low levels of dispersal seen in California populations of $P$. dolus result from selective pressures associated with habitat persistence as well as isolation. In a patchy environment over time, the constant loss of winged dispersers from isolated patches results in a rapid increase in the proportion of nondispersers to dispersers (Roff 1986b, 1990). The configuration of planthopper habitats in southern California conforms to such a situation in which most dispersal would be disadvantageous. There, Spartina marshes are nestled in isolated bays and are widely separated by uninhabitable coast (Zedler 1982, 1993, Zedler et al. 1992). For instance, the marsh at Point Mugu occurs nearly $100 \mathrm{~km}$ north of the next nearest Spartina marsh complex in the Anaheim-Newport area, which occurs $130 \mathrm{~km}$ north of the next nearest Spartina marshes in Mission Bay (Zedler 1982). Similarly, most of the Spartina marshes in Baja California are separated by distances of $100 \mathrm{~km}$ or more (Roberts 1989). Furthermore, within most of these isolated marshes, Spartina grows as a fragmented archipelago of very small, isolated patches (Zedler 1993), a situation which differs from the extensive expanses of Spartina that occur along most of the Atlantic and Gulf coasts (Adams 1963, Duncan 1974, Turner and Gosselink 1975, Turner 1976, Stout 1984).

That habitat isolation influences dispersal capability can be seen in the density-wing form responses of New Jersey and East Tampa populations of $P$. dolus (Fig. 8). High-marsh habitats are persistent at both locations, but Spartina is very patchy at its southern limit in East Tampa (Duncan 1974, Turner 1976). Although relatively low levels of macropters are produced under crowded conditions for both populations, significantly fewer macropters are produced in the East Tampa population. Overall, however, it appears that selection imposed by habitat persistence, coupled with high levels of gene flow, has had a stronger influence on the evolution of dispersal strategies in local Prokelisia populations than has selection imposed by habitat isolation.

Our argument for the role of selection in determining the dispersal strategies of Prokelisia planthoppers is strengthened by data that suggest that intraspecific variation in the dispersal capability of both Prokelisia species has a genetic basis. The evidence for this assertion stems from our common-garden experiment in which the production of macropters in Atlantic and Gulf coast populations of both Prokelisia species paralleled field levels of macroptery observed in the source populations (Fig. 8). Although our experiment was potentially confounded by maternal effects, which have been shown to influence wing form in some insects (Dixon 1985, Messina 1987, 1993, Dingle 1991), previous studies on planthoppers including $P$. marginata have indicated that maternal effects on wing form are nonexistent or weak at best (reviewed in Denno et al. 1991). Thus, the most plausible explanation for the geographic variation in wing form in both Prokelisia species is that it reflects genetically based differences in dispersal strategies. The selective differences operating to maintain the striking contrast in the dispersal strategies of Atlantic and Gulf coast populations of $P$. marginata must be great, since the populations differ despite high levels of gene flow across peninsular Florida (M. A. Peterson and R. F. Denno, unpublished data).

To date, the vast majority of evidence supporting the habitat persistence-dispersal hypothesis is qualitative and based on crude estimates of habitat variability (see Southwood 1962 and Roff 1990 for a discussion). Many of these assessments have shown a tentative link between habitat persistence and interspecific variation in dispersal (Southwood 1962, Vepsäläinen 1978, den Boer et al. 1980, Brown 1986, Roff 1990). However, most studies are compromised by the failure to control for possible phylogenetic nonindependence (but see Denno et al. 1991). Herein, we capitalized on intraspecific variation in dispersal capability (percent macroptery) to examine the relationship between habitat persistence and dispersal, thereby minimizing possible phylogenetic effects. To establish this relationship, we employed a rigorous assay of habitat persistence based on the ability of Prokelisia planthoppers to endure winter in their primary habitat for development. The results of this study provide the strongest evidence to date that intraspecific variation in the dispersal capability of insects is inversely related to the persistence of their habitats.

\section{ACKNOWLEDGMENTS}

We thank Daphne Fairbairn, Frank Messina, Derek Roff, Joy Zedler, and two anonymous reviewers for their insightful suggestions on earlier drafts of this report. Joy Zedler also provided additional details concerning the structure of southern California salt marshes. Ronald Dow kindly granted us access to the marshes on the Pacific Missile Test Center, Point Mugu, CA. Al and Mary Helen Steinhauer, Jon and Barb Moulding, Paul and Ann Tuskes, and Rob and Heidi Everich offered various combinations of us a very needed respite from the mud, sweat, and biting flies. We are most grateful to all of these colleagues. This research was supported by National Science Foundation Grants BSR-8206603 and BSR-8614561 to R. F. Denno. This is Scientific Article Number A-7801, Contribution Number 9123 of the Maryland Agricultural Experiment Station, Department of Entomology. 


\section{Literature Cited}

Aberle, B. 1990. The biology, control, and eradication of introduced Spartina (Cordgrass) worldwide and recommendations for its control in Washington. Washington State Department of Natural Resources, Seattle, Washington, USA.

Adams, D. A. 1963. Factors influencing vascular plant zonation in North Carolina salt marshes. Ecology 44:445456.

Anderson, C. M., and M. Treshow. 1980. A review of environmental and genetic factors that affect height in Spartina alterniflora Loisel. (salt marsh cordgrass). Estuaries 3: 168-176.

Antolin, M. F., and D. R. Strong. 1987. Long-distance dispersal by a parasitoid (Anagrus delicatus, Mymaridae) and its host. Oecologia 73:288-292.

Blum, J. L. 1968. Salt marsh spartinas and associated algae. Ecological Monographs 38:199-221.

Brown, V. K. 1986. Life cycle strategies and plant succession. Pages 105-124 in F. Taylor and R. Karban, editors. The evolution of insect life cycles. Springer-Verlag, New York, New York, USA.

Cagampang, G. B., M. D. Pathak, and B. O. Juliano. 1974. Metabolic changes in the rice plant during infestation by the brown planthopper, Nilaparvata lugens Stål (Hemiptera: Delphacidae). Applied Entomology and Zoology 9:174184.

Callaway, J. C., and M. N. Josselyn. 1992. The introduction and spread of smooth cordgrass (Spartina alterniflora) in South San Francisco Bay. Estuaries 15:218-226.

Cook, A., and R. F. Denno. 1994. Planthopper/plant interactions: feeding behavior, plant nutrition, plant defense and host plant specialization. Pages 114-139 in R. F. Denno and T. J. Perfect, editors. Planthoppers: their ecology and management. Chapman and Hall, New York, New York, USA.

Crowley, P. H. 1981. Dispersal and stability of predatorprey interactions. American Naturalist 118:673-701.

Daehler, C. C., and D. R. Strong. 1994. Variable reproductive output among clones of Spartina alterniflora (Poaceae) invading San Francisco Bay, California: the influence of herbivory, pollination, and establishment site. American Journal of Botany 81:307-313.

den Boer, P. J. 1981. On the survival of populations in a heterogeneous and variable environment. Oecologia (Berlin) 50:39-53.

den Boer, P. J., H. P. T. Van Huizen, W. Den-Daanje, B. Aukema, and C. F. M. Den Bieman. 1980. Wing polymorphism and dimorphism in ground beetles as stages in an evolutionary process (Coleoptera: Carabidae). Entomologia Generalis 6:107-134.

Denno, R. F. 1983. Tracking variable host plants in space and time. Pages 291-341 in R. F. Denno and M. S. McClure, editors. Variable plants and herbivores in natural and managed systems. Academic Press, New York, New York, USA.

1988. Planthoppers on the move. Natural History Magazine 97:40-47.

- 1994a. Influence of habitat structure on the abundance and diversity of planthoppers. Pages 140-159 in R F. Denno and T. J. Perfect, editors. Planthoppers: their ecology and management. Chapman and Hall, New York, New York, USA.

1994b. Life history variation in planthoppers. Pages 163-215 in R. F. Denno and T. J. Perfect, editors. Planthoppers: their ecology and management. Chapman and Hall, New York, New York, USA.

Denno, R. F., J. Cheng, G. K. Roderick, and T. J. Perfect. 1994. Density-related effects on the components of fitness and population dynamics of planthoppers. Pages 257-281 in R. F. Denno and T. J. Perfect, editors. Planthoppers: their ecology and management. Chapman and Hall, New York, New York, USA.

Denno, R. F., L. W. Douglass, and D. Jacobs. 1985. Crowding and host plant nutrition: environmental determinants of wing-form in Prokelisia marginata. Ecology 66:15881596.

Denno, R. F., L. W. Douglass, and D. Jacobs. 1986. Effects of crowding and host plant nutrition on a wing-dimorphic planthopper. Ecology 67:116-123.

Denno, R. F., and E. E. Grissell. 1979. The adaptiveness of wing-dimorphism in the salt marsh-inhabiting planthopper, Prokelisia marginata (Homoptera: Delphacidae). Ecology 60:221-236.

Denno, R. F., K. L. Olmstead, and E. S. McCloud. 1989. Reproductive cost of flight capability: a comparison of life history traits in wing dimorphic planthoppers. Ecological Entomology 14:31-44.

Denno, R. F., and M. A. Peterson. 1995. Density-related dispersal and its consequences for population dynamics. Pages 113-130 in N. Cappuccino and P. W. Price, editors. Populations dynamics: new approaches and synthesis. Academic Press, New York, New York, USA.

Denno, R. F., M. J. Raupp, D. W. Tallamy, and C. F. Reichelderfer. 1980. Migration in heterogeneous environments: differences in habitat selection between the wing forms of the dimorphic planthopper, Prokelisia marginata (Homoptera: Delphacidae). Ecology 61:859-867.

Denno, R. F., and G. K. Roderick. 1990. Population biology of planthoppers. Annual Review of Entomology 35:489520.

Denno, R. F., and G. K. Roderick. 1992. Density-related dispersal in planthoppers: effects of interspecific crowding. Ecology 73:1323-1334.

Denno, R. F., G. K. Roderick, K. L. Olmstead, and H. G. Döbel. 1991. Density-related migration in planthoppers (Homoptera: Delphacidae): the role of habitat persistence. American Naturalist 138:1513-1541.

Denno, R. F., M. E. Schauff, S. W. Wilson, and K. L. Olmstead. 1987. Practical diagnosis and natural history of two sibling salt marsh-inhabiting planthoppers in the genus Prokelisia (Homoptera:Delphacidae). Proceedings of the Entomological Society of Washington 89:687-700.

Dingle, H. 1978. Migration and diapause in tropical, temperate, and island milkweed bugs. Pages $254-276$ in $\mathrm{H}$ Dingle, editor. The evolution of insect migration and diapause. Springer-Verlag, New York, New York, USA.

1985. Migration. Pages 375-415 in G. A. Kerkut and L. I. Gilbert, editors. Comprehensive insect physiology, biochemistry and pharmacology, Volume 9, Behavior. Pergamon, New York, New York, USA.

. 1991. Evolutionary genetics of animal migration. American Zoologist 31:253-264.

Dixon, A. F. G. 1985. Aphid ecology. Blackie and Sons, London, England.

Duncan, W. H. 1974. Vascular halophytes of the Atlantic and Gulf coasts of North America north of Mexico. Pages 2350 in R. J. Reimold and W. H. Queen, editors. Ecology of halophytes. Academic Press, New York, New York, USA

Ebenhard, T. 1991. Colonization in metapopulations: a review of theory and observations. Biological Journal of the Linnean Society 42:105-121.

Edwards, J. S., and P. Sugg. 1993. Arthropod fallout as a resource in the recolonization of Mount St. Helens. Ecology 74:954-958.

Fahrig, L. 1990. Interacting effects of disturbance and dispersal on individual selection and population stability. Comments on Theoretical Biology 1:275-297.

Fairbairn, D. J. 1986. Does alary dimorphism imply dispersal polymorphism in the waterstrider, Gerris remigis? Ecological Entomology 11:355-368. 
-1988. Adaptive significance of wing dimorphism in the absence of dispersal: a comparative study of wing morphs in the waterstrider, Gerris remigis. Ecological Entomology 13:273-281.

Fairbairn, D. J., and L. Desranleau. 1987. Flight threshold, wing muscle histolysis, and alary polymorphism: correlated traits for dispersal tendency in the Gerridae. Ecological Entomology 12:13-24.

Gallagher, J. L., G. F. Somers, D. M. Grant, and D. M. Seliskar. 1988. Persistent differences in two forms of Spartina alterniflora: a common garden experiment. Ecology 69: 1005-1008.

Hamilton, W. D., and R. M. May. 1977. Dispersal in stable habitats. Nature 269:578-581.

Hansson, L. 1991. Dispersal and connectivity in metapopulations. Biological Journal of the Linnean Society 42:89103.

Harrison, R. G. 1980. Dispersal polymorphisms in insects Annual Review of Ecology and Systematics 11:95-118.

Harrison, S. 1991. Local extinction in a metapopulation context: an empirical evaluation. Biological Journal of the Linnean Society 42:73-88.

Hastings, A. 1982. Dynamics of a single species in a spatially varying environment: the stabilizing role of high dispersal rates. Journal of Mathematical Biology 16:49-56.

Hatcher, B. G., and K. H. Mann. 1975. Above-ground productivity of marsh cordgrass (Spartina alterniflora) near the northern end of its range. Journal of the Fisheries Research Board of Canada 32:83-87.

Iwanaga, K., F. Nakasuji, and S. Tojo. 1987. Wing polymorphism in Japanese and foreign strains of the brown planthopper, Nilaparvata lugens. Entomologia Experimentalis et Applicata 43:3-10.

Johnson, K. 1991. The effects of host quality on a phytophagous insect (Homoptera: Delphacidae) and its predators in a California salt marsh. Thesis. Department of Biology, San Diego State University, California, USA.

Kirby, C. J., and J. G. Gosselink. 1976. Primary production in a Louisiana Gulf coast Spartina alterniflora marsh. Ecology 57:1052-1059.

Kisimoto, R. 1965. Studies on polymorphism and its role playing in the population growth of the brown planthopper, Nilaparvata lugens Stål. Bulletin of the Shikoku Agricultural Experiment Station 13:1-106.

Kurz, H., and D. Wagner. 1957. Tidal marshes of the Gulf and Atlantic coasts of north Florida and Charleston, South Carolina. Florida State University Studies 24:1-168.

Leigh, E. G., Jr. 1981. The average lifetime of a population in a varying environment. Journal of Theoretical Biology 90:213-239.

Masaki, S. 1973. Climatic adaptation and photoperiodic response in the band-legged ground cricket. Evolution 26: 587-600.

McCoy, E. D., and J. R. Rey. 1981. Patterns of abundance, distribution, and alary polymorphism among salt marsh Delphacidae (Homoptera: Fulgoroidea) of northwest Florida. Ecological Entomology 6:285-291.

Mendelsshon, I. A., K. L. McKey, and W. H. Patrick, Jr. 1981. Oxygen deficiency in Spartina alterniflora roots: metabolic adaptation to anoxia. Science 214:439-441.

Messina, F. J. 1987. Genetic contribution to the dispersal polymorphism of the cowpea weevil (Coleoptera: Bruchidae). Annals of the Entomological Society of America 80: 12-16.

- 1993. Effect of initial colony size on the per capita growth rate and alate production of the Russian wheat aphid (Homoptera: Aphididae). Journal of the Kansas Entomological Society 66:365-371.

Miller, W. R., and F. E. Egler. 1950. Vegetation of the We-
quetequock-Pawcatuck tidal-marshes, Connecticut. Ecological Monographs 20:145-172.

Mobberley, D. G. 1956. Taxonomy and distribution of the genus Spartina. Iowa State College Journal of Science $\mathbf{3 0}$ 471-574.

Neuenschwander, L. F., T. H. Thorsted, and R. J. Vogl. 1979 The salt marsh and transitional vegetation of Bahía de San Quintín. Bulletin of the Southern California Academy of Science 78: 163-182.

Niering, W. A., and R. S. Warren. 1980. Vegetation patterns and processes in New England salt marshes. Bioscience 30: 301-307.

Ornes, W. H., and D. I. Kaplan. 1989. Macronutrient status of tall and short forms of Spartina alterniflora in a South Carolina salt marsh. Marine Ecology Progress Series 55 63-72.

Pearce, E. A., and G. Smith. 1990. The times books world weather guide. Random House, New York, New York, USA.

Peterson, M. A., and R. F. Denno. In press. Life history strategies and the genetic structure of phytophagous insect populations. In S. Mopper and S. Strauss, editors. Host plant effects on local genetic variation in natural insect populations. Chapman and Hall, New York, New York, USA.

Raatikainen, M. 1967. Bionomics, enemies and population dynamics of Javesella pellucida (F.) (Homoptera, Delphacidae). Annales Agriculturae Fenniae 6:1-149.

Reddingius, J., and P. J. den Boer. 1970. Simulation experiments illustrating stabilization of animal numbers by spreading of risk. Oecologia (Berlin) 15:240-284

Redfield, A. C. 1972. The development of a New England salt marsh. Ecological Monographs 42:201-237.

Roberts, N. C. 1989. Baja California plant field guide. Natural History, La Jolla, California, USA.

Roderick, G. K. 1987. Ecology and evolution of dispersal in California populations of a salt marsh insect, Prokelisia marginata. Dissertation. University of California, Berkeley, California, USA.

Roderick, G. K. 1996. Geographic structure of insect populations: gene flow, phylogeography, and their uses. Annual Review of Entomology 41:325-352.

Roff, D. A. 1974a. Spatial heterogeneity and the persistence of populations. Oecologia (Berlin) 15:245-258.

- $1974 b$. The analysis of a population model demonstrating the importance of dispersal in a heterogeneous environment. Oecologia (Berlin) 15:259-275.

- 1984. The cost of being able to fly: a study of wing polymorphism in two species of crickets. Oecologia (Berlin) 63:30-37.

1986a. The evolution of wing dimorphism in insects. Evolution 40:1009-1020.

- 1986b. Evolution of wing polymorphism and its impact on life cycle adaptation in insects. Pages 204-221 in $\mathrm{F}$. Taylor and $\mathrm{R}$. Karban, editors. The evolution of insect life cycles. Springer-Verlag, New York, New York, USA.

. 1990. The evolution of flightlessness in insects. Ecological Monographs 60:389-421.

. 1994. Habitat persistence and the evolution of wing dimorphism in insects. American Naturalist 144:772-798.

Roff, D. A., and D. J. Fairbairn. 1991. Wing dimorphism and the evolution of migratory polymorphisms among the Insecta. American Zoologist 31:243-251.

SAS. 1990. SAS user's guide. SAS Institute, Cary, North Carolina, USA.

Slatkin, M. 1985. Gene flow in natural populations. Annual Review of Ecology and Systematics 16:393-430.

Solbreck, C. 1978. Migration, diapause, and direct development as alternative life histories in a seed bug, Neacoryphus bicrucis. Pages 195-217 in $\mathrm{H}$. Dingle, editor. The 
evolution of insect migration and diapause. Springer-Verlag, New York, New York, USA.

Southwood, T. R. E. 1962. Migration of terrestrial arthropods in relation to habitat. Biological Review 27:171-214.

- 1977. Habitat, the templet for ecological strategies. Journal of Animal Ecology 46:337-365.

Southwood, T. R. E., R. M. May, M. P. Hassell, and G. R. Conway. 1974. Ecological strategies and population parameters. American Naturalist 108:791-804.

Sparks, A. N., R. D. Jackson, J. E. Carpenter, and R. A. Muller. 1986. Insects captured in light traps in the Gulf of Mexico. Annals of the Entomological Society of America 79:132-139.

Squiers, E. R., and R. E. Good. 1974. Seasonal changes in the productivity, caloric content, and chemical composition of a population of salt-marsh cordgrass (Spartina alterniflora). Chesapeake Science 15:63-71.

Stiller, J. W., and A. L. Denton. 1995. One hundred years of Spartina alterniflora (Poaceae) in Willapa Bay, Washington: random amplified polymorphic DNA analysis of an invasive population. Molecular Biology 4:355-363.

Stout, J. P. 1984. The ecology of irregularly flooded salt marshes of the north-eastern Gulf of Mexico: a community profile. U.S. Fish and Wildlife Service Biological Report 85(7.1).

Strong, D. R., and P. D. Stiling. 1983. Wing dimorphism changed by experimental density manipulation in a planthopper, Prokelisia marginata (Homoptera: Delphacidae). Ecology 64:206-209.

Tallamy, D. W., and R. F. Denno. 1979. Responses of sapfeeding insects (Homoptera: Hemiptera) to simplification of host plant structure. Environmental Entomology 8:10211028.

Taylor, F, and R. Karban. 1986. The evolution of insect life cycles. Springer-Verlag, New York, New York, USA.

Teal, J. M. 1962. Energy flow in the salt marsh ecosystem of Georgia. Ecology 43:614-624.

Throckmorton, A. E. 1989. The effects of tidal inundation, spider predation, and dispersal on the population dynamics of Prokelisia marginata. Dissertation. The Florida State University, Tallahassee, Florida, USA.

Tide Tables. 1992. East Coast of North and South America. U.S. Department of Commerce, National Oceanic and Atmospheric Administration, National Ocean Service, Washington, D.C.
1993. West Coast of North and South America. U.S. Department of Commerce, National Oceanic and Atmospheric Administration, National Ocean Service, Washington, D.C.

Turner, R. E. 1976. Geographic variation in salt marsh macrophyte production: A review. Contributions in Marine Science 20:47-68.

Turner, R. E., and J. G. Gosselink. 1975. A note on standing crops of Spartina alterniflora in Texas and Florida. Contributions in Marine Science 19:113-118.

Ustin, S. L., R. W. Pearcy, and D. E. Bayer. 1982. Plant water relations in a San Francisco Bay salt marsh. Botanical Gazette 143:368-373.

Vance, R. R. 1980. The effect of dispersal on population size in a temporally varying environment. Theoretical Population Biology 18:343-362.

Vepsäläinen, K. 1978. Wing dimorphism and diapause in Gerris: determination and adaptive significance. Pages 218-253 in H. Dingle, editor. Evolution of insect migration and diapause. Springer-Verlag, New York, New York, USA

Vince, S. W., I. Valiela, and J. M. Teal. 1981. An experimental study of the structure of herbivorous insect communities in a salt marsh. Ecology 62:1662-1678.

Wagner, D. L., and J. K. Liebherr. 1992. Flightlessness in insects. Trends in Ecology and Evolution 7:216-220.

Wilson, S. W. 1982. The planthopper genus Prokelisia in the United States (Homoptera: Fulgoroidea: Delphacidae). Journal of the Kansas Entomological Society 55:532-546.

Zedler, J. B. 1982. The ecology of southern California coastal salt marshes: a community profile. U.S. Fish and Wildlife Service, Biological Services Program, Washington, D.C. FWS/OBS-81/54.

- 1993. Canopy architecture of natural and planted cordgrass marshes: Selecting habitat evaluation criteria. Ecological Applications 3:123-138.

Zedler, J. B., C. S. Nordby, and B. E. Kus. 1992. The ecology of Tijuana Estuary, California: a national estuarine research reserve. Office of Coastal Resource Management, Sanctuaries and Reserves Division, National Oceanic and Atmospheric Administration, Washington, D.C.

Zera, A. J. 1984. Differences in survivorship, development rate and fertility between the longwinged and wingless morphs of the waterstrider, Limnoporus coniculatus. Evolution 38:1023-1032. 


\section{APPENDIX}

Locations of specific North American intertidal marshes from which Prokelisia planthoppers were sampled. For each location, the growth form of Spartina present (tall-form and/or short-form) and sampled for planthoppers is shown. Also listed are the sampling date(s) and sample sizes of both $P$. marginata and $P$. dolus. Data are sorted into four geographic regions: Atlantic coast (both Prokelisia species), Gulf coast (both Prokelisia species), Pacific coast in northern California (only P. marginata), and Pacific coast in southern and Baja California (only P. dolus).

\begin{tabular}{|c|c|c|c|c|c|}
\hline $\begin{array}{l}\text { Site } \\
\text { no. }\end{array}$ & Location & $\begin{array}{l}\text { Spartina } \\
\text { growth } \\
\text { form sampled }\end{array}$ & Sample date & $\begin{array}{l}\text { P. marginata } \\
\text { (sample } \\
\text { size) }\end{array}$ & $\begin{array}{c}P . \text { dolus } \\
\text { (sample } \\
\text { size) }\end{array}$ \\
\hline \multicolumn{6}{|c|}{ Atlantic coast } \\
\hline 1 & La Pocatiere, Kamouraska County, Quebec & Tall, short & August 1989 & 0 & 0 \\
\hline 2 & Riviere-du-Loup, Riviere-du-Loup County, Quebec & Tall, short & August 1989 & 0 & 0 \\
\hline 3 & Rimouski, Rimouski County, Quebec & Tall, short & August 1989 & 0 & 0 \\
\hline 4 & Campbellton, Restigouche County, New Brunswick & Tall & August 1989 & 0 & 0 \\
\hline 5 & Bathurst, Gloucester County, New Brunswick $\dagger$ & Tall, short & August 1989 & 0 & 3799 \\
\hline 6 & Cocagne, Kent County, New Brunswick & Short & August 1989 & 0 & 24 \\
\hline 7 & Shediac, Westmorland County, New Brunswick $\dagger$ & Tall, short & August 1989 & 0 & 891 \\
\hline 8 & Shemogue, Westmorland County, New Brunswick & Short & August 1989 & 0 & 288 \\
\hline 9 & Baie Verte, Westmorland County, New Brunswick & Tall & August 1989 & 0 & 220 \\
\hline 10 & Pugwash, Cumberland County, Nova Scotia & Tall & August 1989 & 0 & 1066 \\
\hline 11 & Antigonish, Antigonish County, Nova Scotia & Tall & August 1989 & 0 & 30 \\
\hline 12 & Ecum Secum, Guysborough County, Nova Scotia $\dagger$ & Tall, short & August 1989 & 0 & 3211 \\
\hline 13 & Beaver Harbour, Halifax County, Nova Scotia & Tall & August 1989 & 0 & 1492 \\
\hline 14 & Sheet Harbour, Halifax County, Nova Scotia & Tall & August 1989 & 0 & 16 \\
\hline 15 & Petpeswick, Halifax County, Nova Scotia & Tall & August 1989 & 0 & 50 \\
\hline 16 & Seaforth, Halifax County, Nova Scotia $†$ & Tall, short & August 1989 & 0 & 176 \\
\hline 17 & Halifax, Halifax County, Nova Scotia & Short & August 1989 & 0 & 259 \\
\hline 18 & Old Barns, Colchester County, Nova Scotia & Tall & August 1989 & 0 & 169 \\
\hline 19 & Amherst, Cumberland County, Nova Scotia $\dagger$ & Tall, short & August 1989 & 0 & 843 \\
\hline 20 & Machias, Washington County, Maine & Tall & August 1994 & 0 & 129 \\
\hline 21 & Bass Harbor, Hancock County, Maine $\dagger$ & Tall, short & August 1989 & 0 & 566 \\
\hline 22 & Warren, Knox County, Maine & Tall & August 1994 & 0 & 266 \\
\hline 23 & Wiscasset, Lincoln County, Maine & Tall & August 1989 & 0 & 31 \\
\hline 24 & Bath, Sagadahoc County, Maine & Tall & August 1989 & 2 & 113 \\
\hline 25 & Scarborough, Cumberland County, Maine $\dagger$ & Tall, short & August 1989 & 1 & 3351 \\
\hline 26 & Seabrook, Rockingham County, New Hampshire $\dagger$ & Tall, short & $\begin{array}{l}\text { August } 1989 \\
\text { August } 1994\end{array}$ & 0 & 5357 \\
\hline 27 & Newbury, Essex County, Massachusetts $\dagger$ & Tall, short & August 1989 & 0 & 2712 \\
\hline 28 & South Duxbury, Plymouth County, Massachusetts & Short & August 1994 & 0 & 41 \\
\hline 29 & Barnstable, Barnstable County, Massachusetts $\dagger$ & Tall, short & August 1989 & 7 & 3802 \\
\hline 30 & Martha's Vineyard, Dukes County, Massachusetts $\dagger$ & Tall, short & August 1989 & 3 & 284 \\
\hline 31 & Sippewissett, Barnstable County, Massachusetts $\dagger$ & Tall, short & August 1989 & 7 & 402 \\
\hline 32 & Barrington, Bristol County, Rhode Island $\S, \dagger$ & Tall, short & August 1989 & 54 & 1585 \\
\hline 33 & Jerusalem, Washington County, Rhode Island $, \|, \dagger, \ddagger$ & Tall, short & $\begin{array}{l}\text { August } 1989, \\
\text { August } 1994, \\
\text { May } 1995\end{array}$ & 191 & 737 \\
\hline 34 & Old Saybrook, Middlesex County, Connecticut & Short & August 1989 & 5 & 220 \\
\hline 35 & Fenwick, Middlesex County, Connecticut & Tall & August 1989 & 41 & 0 \\
\hline 36 & Westport, Fairfield County, Connecticut & Tall & August 1989 & 6808 & 4 \\
\hline 37 & Greens Farms, Fairfield County, Connecticut $\S, \|, \dagger, \ddagger$ & Tall, short & $\begin{array}{c}\text { August } 1989, \\
\text { August } 1994, \\
\text { May } 1995\end{array}$ & 1784 & 278 \\
\hline 38 & Saugatuck, Fairfield County, Connecticut & Tall & August 1994 & 12 & 12 \\
\hline 39 & Tuckerton, Ocean County, New Jersey $\S, \|, \dagger, \ddagger$ & Tall, short & $\begin{array}{l}\text { July 1985, April } \\
\text { 1986, July } 1986\end{array}$ & 9627 & 3324 \\
\hline 40 & Slaughter Beach, Sussex County, Delaware $\S, \|, \dagger, \ddagger$ & Tall, short & $\begin{array}{l}\text { August } 1988 \\
\text { April } 1995\end{array}$ & 4406 & 2611 \\
\hline 41 & Kent Island, Queen Annes County, Maryland & Short & September 1988 & 57 & 22 \\
\hline 42 & George Island, Worcester County, Maryland $\S, \dagger$ & Tall, short & May 1988 & 406 & 1005 \\
\hline 43 & Chincoteague, Acomack County, Virginia $\S, \|, \dagger, \ddagger$ & Tall, short & $\begin{array}{l}\text { April } 1995, \\
\text { July } 1995\end{array}$ & 294 & 550 \\
\hline 44 & Wachapreague, Acomack County, Virginia§, $†$ & Tall, short & May 1988 & 896 & 33 \\
\hline 45 & Virginia Beach, Chesapeake County, Virginia $\S, \dagger$ & Tall, short & September 1994 & 538 & 188 \\
\hline 46 & Wanchese, Dare County, North Carolina & Tall, short & May 1994 & 232 & 1855 \\
\hline 47 & Beaufort, Carteret County, North Carolina $\S, \dagger$ & Tall, short & May 1988 & 644 & 67 \\
\hline 48 & Swansboro, Onslow County, North Carolina§, $†$ & Tall, short & May 1994 & 383 & 94 \\
\hline 49 & $\begin{array}{l}\text { Wrightsville Beach, New Hanover County, North } \\
\text { Carolina§, } \dagger\end{array}$ & Tall, short & May 1988 & 55 & 165 \\
\hline 50 & Sunset Beach, Brunswick County, North Carolina $\S$ & Tall, short & May 1994 & 34 & 21 \\
\hline 51 & $\begin{array}{l}\text { Pawleys Island, Georgetown County, South Caroli- } \\
\text { naß,† }\end{array}$ & Tall, short & May 1988 & 40 & 506 \\
\hline
\end{tabular}


APPENDIX. Continued.

\begin{tabular}{|c|c|c|c|c|c|}
\hline $\begin{array}{l}\text { Site } \\
\text { no. }\end{array}$ & Location & $\begin{array}{l}\text { Spartina } \\
\text { growth } \\
\text { form sampled }\end{array}$ & Sample date & $\begin{array}{l}\text { P. marginata } \\
\text { (sample } \\
\text { size) }\end{array}$ & $\begin{array}{l}\text { P. dolus } \\
\text { (sample } \\
\text { size) }\end{array}$ \\
\hline 52 & Whitehall Terrace, Berkeley County, South Carolina & Tall, short & May 1994 & 62 & 122 \\
\hline 53 & Edisto Island, Colleton County, South Carolina§, $\dagger$ & Tall, short & May 1988 & 398 & 133 \\
\hline 54 & Tybee Island, Effingham County, Georgia & Tall, short & May 1994 & 230 & 25 \\
\hline 55 & Savannah, Effingham County, Georgia & Tall, short & May 1994 & 31 & 25 \\
\hline 56 & Harris Neck, McIntosh County, Georgia§, $\dagger$ & Tall, short & May 1988 & 52 & 63 \\
\hline 57 & Jekyll Island, Glynn County, Georgia§, $\uparrow$ & Tall, short & May 1988 & 302 & 264 \\
\hline 58 & Fernandina Beach, Nassau County, Florida§, $\dagger$ & Tall, short & May 1988 & 47 & 139 \\
\hline 59 & Mayport, Duval County, Florida $\S, \dagger$ & Tall, short & May 1988 & 113 & 159 \\
\hline 60 & Ponte Vedra Beach, St. Johns County, Florida & Tall, short & May 1994 & 4 & 68 \\
\hline 61 & Crescent Beach, St. Johns County, Florida $§$ & Tall, short & May 1988 & 198 & 201 \\
\hline 62 & Marineland, Flagler County, Florida & Tall & October 1976 & 0 & 86 \\
\hline 63 & Port Orange, Volusia County, Florida $†$ & Tall, short & May 1994 & 63 & 614 \\
\hline 64 & Oak Hill, Volusia County, Florida & Tall & May 1994 & 0 & 109 \\
\hline \multicolumn{6}{|c|}{ Gulf coast } \\
\hline 65 & Anton Lizardo, Veracruz, Mexico & Tall & December 1987 & 0 & 228 \\
\hline 66 & S. Padre Island, Cameron County, Texas $\|$ & Tall, short & $\begin{array}{l}\text { December } 1989 \\
\text { May } 1994\end{array}$ & 1085 & 0 \\
\hline 67 & Port Isabel, Cameron County, Texas\|, & Tall, short & $\begin{array}{l}\text { December } 1989 \\
\text { May } 1994\end{array}$ & 4398 & 79 \\
\hline 68 & Corpus Christi, Nueces County, Texas & Tall, short & December 1989 & 14 & 244 \\
\hline 69 & Port Aransas, Nueces County, Texas $\S, \dagger$ & Tall, short & May 1994 & 55 & 67 \\
\hline 70 & Rockport, Aransas County, Texas & Tall, short & December 1989 & 1117 & 842 \\
\hline 71 & Matagorda, Matagorda County, Texas§, $†$ & Tall, short & May 1994 & 139 & 438 \\
\hline 72 & Gilchrist, Chambers County, Texas§, $\dagger$ & Tall, short & May 1994 & 1204 & 2839 \\
\hline 73 & Oak Grove, Cameron Parish, Louisiana§, $\dagger$ & Tall, short & May 1994 & 32 & 118 \\
\hline 74 & Cocodrie, Terrebonne Parish, Louisiana $\$, \dagger$ & Tall, short & May 1994 & 39 & 87 \\
\hline 75 & Port Sulphur, Plaquemines Parish, Louisiana & Tall, short & December 1990 & 0 & 177 \\
\hline 76 & Buras, Plaquemines Parish, Louisiana & Tall, short & December 1990 & 0 & 129 \\
\hline 77 & Waveland, Hancock County, Mississippi\|, ‡ & Tall, short & December 1990 & 138 & 161 \\
\hline 78 & Pass Christian, Harrison County, Mississippi§, $\dagger$ & Tall, short & May 1994 & 247 & 30 \\
\hline 79 & Dauphin Island, Mobile County, Alabama & Tall, short & December 1990 & 86 & 18 \\
\hline 80 & Fort Morgan, Baldwin County, Alabama & Tall, short & May 1994 & 597 & 304 \\
\hline 81 & Destin, Okaloosa County, Florida & Tall & May 1994 & 71 & 23 \\
\hline 82 & Eastpoint, Franklin County, Florida $\dagger$ & Tall, short & May 1994 & 964 & 700 \\
\hline 83 & Dekle Beach, Taylor County, Florida $\S, \dagger$ & Tall, short & June 1987 & 2035 & 31 \\
\hline 84 & Cedar Key, Levy County, Florida§, $\|, \dagger, \ddagger$ & Tall, short & $\begin{array}{l}\text { May 1987, May } \\
1988, \text { February } \\
1995\end{array}$ & 1477 & 231 \\
\hline 85 & Pine Island, Hernando County, Florida $§$ & Tall & June 1987 & 106 & 50 \\
\hline 86 & Anclote, Pasco County, Florida & Short & June 1987 & 3 & 115 \\
\hline 87 & Riverview, Hillsborough County, Florida, & Tall, short & May 1988 & 1555 & 639 \\
\hline 88 & Gibsonton, Hillsborough County, Florida & Tall, short & June 1987 & 15 & 148 \\
\hline 89 & East Tampa, Hillsborough County, Florida $\dagger$ & Tall, short & May 1994 & 103 & 509 \\
\hline 90 & Archie Creek, Hillsborough County, Florida & Tall, short & June 1987 & 78 & 416 \\
\hline \multicolumn{6}{|c|}{$\begin{array}{l}\text { Pacific coast } \\
\text { (northern California) }\end{array}$} \\
\hline 91 & Bodega Bay, Sonoma County, California & Tall, short & August 1988 & 30 & 0 \\
\hline 92 & Drakes Estero, Marin County, California & Tall & August 1988 & 72 & 0 \\
\hline 93 & Bolinas, Marin County, California§,\| & Tall, short & August 1988 & 1352 & 0 \\
\hline 94 & Stinson Beach, Marin County, California & Tall, short & August 1988 & 823 & 0 \\
\hline 95 & Corte Madera, Marin County, California & Tall, short & August 1988 & 475 & 0 \\
\hline 96 & China Camp, Marin County, California & Tall, short & August 1988 & 618 & 0 \\
\hline 97 & Petaluma River, Marin County, California & Tall, short & August 1988 & 615 & 0 \\
\hline 98 & Skaggs Island, Napa County, California & Tall & August 1988 & 412 & 0 \\
\hline 99 & Vallejo, Solano County, California & Tall & August 1988 & 1227 & 0 \\
\hline 100 & Emeryville, Alameda County, California & Tall, short & August 1988 & 821 & 0 \\
\hline 101 & Alameda, Alameda County, California & Tall, short & August 1988 & 845 & 0 \\
\hline 102 & East Palo Alto, San Mateo County, California & Tall, short & August 1988 & 551 & 0 \\
\hline 103 & Palo Alto, Santa Clara County, California & Tall, short & August 1988 & 615 & 0 \\
\hline \multicolumn{6}{|c|}{ (southern and Baja California) } \\
\hline 104 & Point Mugu, Ventura County, California & Tall & $\begin{array}{l}\text { June } 1986 \text {, Febru- } \\
\text { ary } 1989\end{array}$ & 0 & 525 \\
\hline 105 & Newport Beach, Orange County, California & Tall & $\begin{array}{l}\text { December } 1978 \text {, } \\
\text { June } 1986\end{array}$ & 0 & 184 \\
\hline 106 & Mission Bay, San Diego County, California & Tall & February 1989 & 0 & 51 \\
\hline 107 & Seaworld, San Diego County, California & Tall & February 1989 & 0 & 79 \\
\hline
\end{tabular}


APPENDIX. Continued.

\begin{tabular}{|c|c|c|c|c|c|}
\hline $\begin{array}{c}\text { Site } \\
\text { no. }\end{array}$ & Location & $\begin{array}{c}\text { Spartina } \\
\text { growth } \\
\text { form sampled }\end{array}$ & Sample date & $\begin{array}{l}P \text {. marginata } \\
\text { (sample } \\
\text { size) }\end{array}$ & $\begin{array}{l}P . \text { dolus } \\
\text { (sample } \\
\text { size) }\end{array}$ \\
\hline 108 & Coronado, San Diego County, California & Tall & February 1989 & 0 & 41 \\
\hline 109 & Chula Vista, San Diego County, California & Tall & February 1989 & 0 & 242 \\
\hline 110 & Tijuana Estuary, San Diego County, California & Tall & June 1986 & 0 & 25 \\
\hline 111 & San Quintin, Baja California Norte, Mexico & Tall, short & February 1990 & 0 & 660 \\
\hline 112 & Guerrero Negro, Baja California Sur, Mexico & Tall & February 1990 & 0 & 889 \\
\hline
\end{tabular}

Notes: Locations used for analysis of the proportional abundance of $P$. dolus in tall- and short-form habitats during the warm season $(\dagger)$ and during the cold season $(\ddagger)$. The table also indicates the locations used for analysis of the proportional abundance of $P$. marginata in tall- and short-form habitats during the warm season (§) and during the cold season $(\|)$. 